\title{
Aquifer assessment for agriculture through geophysical, hydrochemical and hydrogeological approaches around Perumattunallur lake, Southern India
}

\author{
A. Antony Ravindran ${ }^{1}$ (1) Nepal Chandra Mondal $^{2} \cdot$ N. Ramanujam ${ }^{3} \cdot$ \\ K. Srinivasamoorthy ${ }^{4}$
}

Received: 30 January 2015 / Accepted: 23 July 2015/Published online: 14 August 2015

(C) Springer International Publishing 2015

\begin{abstract}
This study mainly focused on aquifer assessment using 2-D Electrical Resistivity Imaging (ERI), hydrochemical, Geographic Information System (GIS)-based analysis and aquifer yield test for agriculture around Perumattunallur lake, Southern India. It comprises on quantifying aquifer thickness and yields with groundwater quality. The 2-D ERI technique was an attempt to study the geological structural and compare with borewell lithologs. The litho units encompass clay, calcrete weathered gneiss rock and charnockites. It shows that the resistivity of the top layer covered by clay/calcrete with kankar ranges of 1-12 $\Omega \mathrm{m}$ followed by fine sand with a resistivity range of (10-20 $\Omega \mathrm{m})$ and calcrete mixed with gneissic rocks with a resistivity range of $20-120 \Omega \mathrm{m}$. The massive charnockite with a resistivity range of $>200 \Omega \mathrm{m}$ is observed in the hill ranges, present in the NE-SW direction. The hydrochemical study was attempted for the parameters (i.e., TDS, $\mathrm{pH}, \mathrm{Na}^{+}, \mathrm{K}^{+}, \mathrm{Ca}^{2+}, \mathrm{Mg}^{2+}$ and $\mathrm{Cl}^{-}$) from bore well water samples briefly displayed by GIS-based geospatial analysis. The geochemical facies analysis of rock-water interaction study was used for the groundwater quality for agriculture.
\end{abstract}

$\triangle$ A. Antony Ravindran

antonicogeo@gmail.com

Nepal Chandra Mondal

ncmngri@gmail.com

1 Department of Geology, V.O. Chidambaram College, Manonmaniam Sundaranar University, Thoothukudi,

Tamilnadu, India

2 Aquifer Mapping Group, CSIR-National Geophysical Research Institute, Hyderabad 500007, India

3 Department of Coastal Disaster Management, Pondicherry Central University, Port Blair, Andaman, India

4 Department of Earth Science, Pondicherry University, Central University, Pondicherry, India
The pumping test helped to determine the aquifer yields with exact determination of the estimation of groundwater supply for agricultural use. The NW side of the wall is a high yield of water discharge from the lake. The average water yield of the study area is about $245.8 \mathrm{~m}^{3} /$ day in summer and $310.6 \mathrm{~m}^{3} /$ day in winter through the selected 7 bore wells. The alluvium clay with a calcrete layer occurs at the SE part and the results show as a low yield due to poor porosity. The radius influence of each well to be taken as $150 \mathrm{~m}$ was identified using the pumping test. The pumping test gives details about an aquifer of leaky aquifer with complex structure of gneissic rock with fracture/fault zone help for aquifer types. The results of the geophysical, hydrochemical and water yield test are used for groundwater quality and quantity for agriculture purpose and domestic use for the sustainable development of groundwater resources in the surroundings of the lake.

Keywords Aquifer mapping - 2-D-ERI .

Hydrochemistry - Aquifer yields · Perumattunallur lake . Southern India

\section{Introduction}

Groundwater is an essential resource for agriculture in India as well as worldwide. The contribution of water for agriculture has been studied by several researchers (Brutsaert and Parlange 1998; Scanlon et al. 2007; Thomas 2008; D̈oll 2009; Siebert et al. 2010). In Indian agriculture and groundwater scenario were also carried out in detail by the previous works (Mall et al. 2006; Deshpande and Aher 2012). It has been observed that the selected site is a part of in and around 20 villages which depend upon agriculture for its full time earning of life. So groundwater mapping is 
an essential part of the selected site due to the irrigation and agriculture. The latest trends of the aquifer mapping study have been carried out by hydrogeologist and geophysicists (Griffiths and Barker1993; Mondal et al. 2008a, b, 2009; Khalil 2009; Aizebeokhai 2010; Selvam et al. 2014). The geophysical study such as electrical resistivity imaging technique is used to estimate the vertical and horizontal changes of subsurface structural changes without any disturbance.

One of the most interesting aspects of hydrochemistry is the occurrence of water bodies with different water chemistries in very close proximity to each other. This has been variously attributed to the surface and subsurface geology (Stallard and Edmond 1983), small climatic differences (Petrović 1980) and groundwater flow direction (Mondal and Singh 2012). Water quality assessment in Akpabuyo, Southeastern Nigeria, indicated that the waters are acidic, soft and characterized by low sodium adsorption ratio, and the waters are also classified into four chemical types, i.e., $\mathrm{Ca}-\mathrm{Cl}_{2}, \mathrm{Na}-\mathrm{Cl}, \mathrm{Ca}-\mathrm{SO}_{4}$ and $\mathrm{Ca}-\mathrm{HCO}_{3}$ (Offiong and Edet 1998). Studies conducted on the chemical quality of groundwater of Mangalore city in Karnataka state and Madras in Tamil Nadu, India, revealed that the groundwater quality has been deteriorated due to its over-exploitation (Ramesh et al. 1995). Sreedevi (2004) had studied the groundwater quality of Pageru River basin in Cuddapah district and the assessment of water samples from various methods proved that majority of the water samples were good either for drinking or agricultural purposes. Presentation of chemical analysis in graphical forms makes the understanding of complex groundwater system simpler and quicker. Several researchers followed a series of methods to interpret and classify the groundwater chemistry in hard rock (Sonkamble et al. 2012; Mondal et al. 2013) as well as soft rock aquifers (Subramanian 1994; Saxena et al. 2003) including coastal zones in Southern India (Mondal et al. 2010, Sankaran et al. 2012). Using GIS technique (Senosy and Dahab 1997; Deev et al. 2012; Antony Ravindran 2013), the quality of groundwater was analyzed for systematic geochemical mapping in the irrigation purpose.

For safe utilization of the available groundwater resources from the existing bore wells to an optimum limit, it is necessary to have comprehensive knowledge about the aquifer potentialities and qualitatively to evaluate all the factors suitability towards drinking water supply as well as irrigation purposes for the local people (Mondal and Das 2012). Thus, the specific yield of bore well, depth of pump installation and duration of the pumping as well as quality of groundwater are essential for augmentation of safe irrigation water supply in any hydrogeological terrain basically where surface water is scanty. Hydrogeologically, the formations are important where the groundwater occurs under unconfined, leaky confined and confined conditions (Todd 1980). But its water table variation is mainly controlled by aquifer characteristics (Sarwade et al. 2007). The different sets of joints, faults and fractures as well as clay material and ash beds play an important role in the circulation, distribution and movement of groundwater. The estimation of yield for irrigation is obtained through only conducting a pumping test.

The shallow and deeper aquifers with Archean rock are occupied in Guduvancherry area near Perumattunallur lake, Southern India which is a good paddy field nearby the Chennai city. The water quality and its GIS-based geospatial variations and aquifer yields are an essential part of agricultural activities (El-Haddad et al. 2014). Thus, the main objectives of this study are threefold: (1) agricultural development through water potential identification, (2) geological, geophysical and hydrochemical mapping using GIS technique, and (3) aquifer yield test through a pumping test.

\section{About the study area}

The study area (Fig. 1) chosen was in Guduvancherry area near Perumattunallur lake, Southern India. The surrounding area is fully covered by forest area. The geologically complex area such as sedimentary origin of alluvium deposits, metamorphic rock of weathered gneiss and quarried are running near the hills for road material of mining is an igneous origin. The area shield is composed of Archean rock. The geological setting is used for the quality and quantity of the groundwater potential in shallow and deeper aquifers. The condition of groundwater is found as a shallow aquifer in a large diameter of open wells. Deep well is artesian aquifer due to the overload of surrounding rocks. The average annual rainfall is about $900-1100 \mathrm{~mm}$ The average temperature is $27^{\circ} \mathrm{C}$.

\section{Materials and methods}

\section{Electrical resistivity imaging}

The 2-D ERI technique was used to map the subsurface structure and faulted/fractured zone in the weathered gneiss and granitic rock (Sudo et al. 2004) which aids in demarcation of groundwater zones. This technique was attempted by WTS-4 Imaging system at five sites (Figs. 1, 2c), multicore cable with electrodes made with Wenner configuration of $10 \mathrm{~m}$ spacing (Dahlin and Loke 1998). The systematic collection of resistivity data was plotted and interpreted using Res2D.INV32 software. 


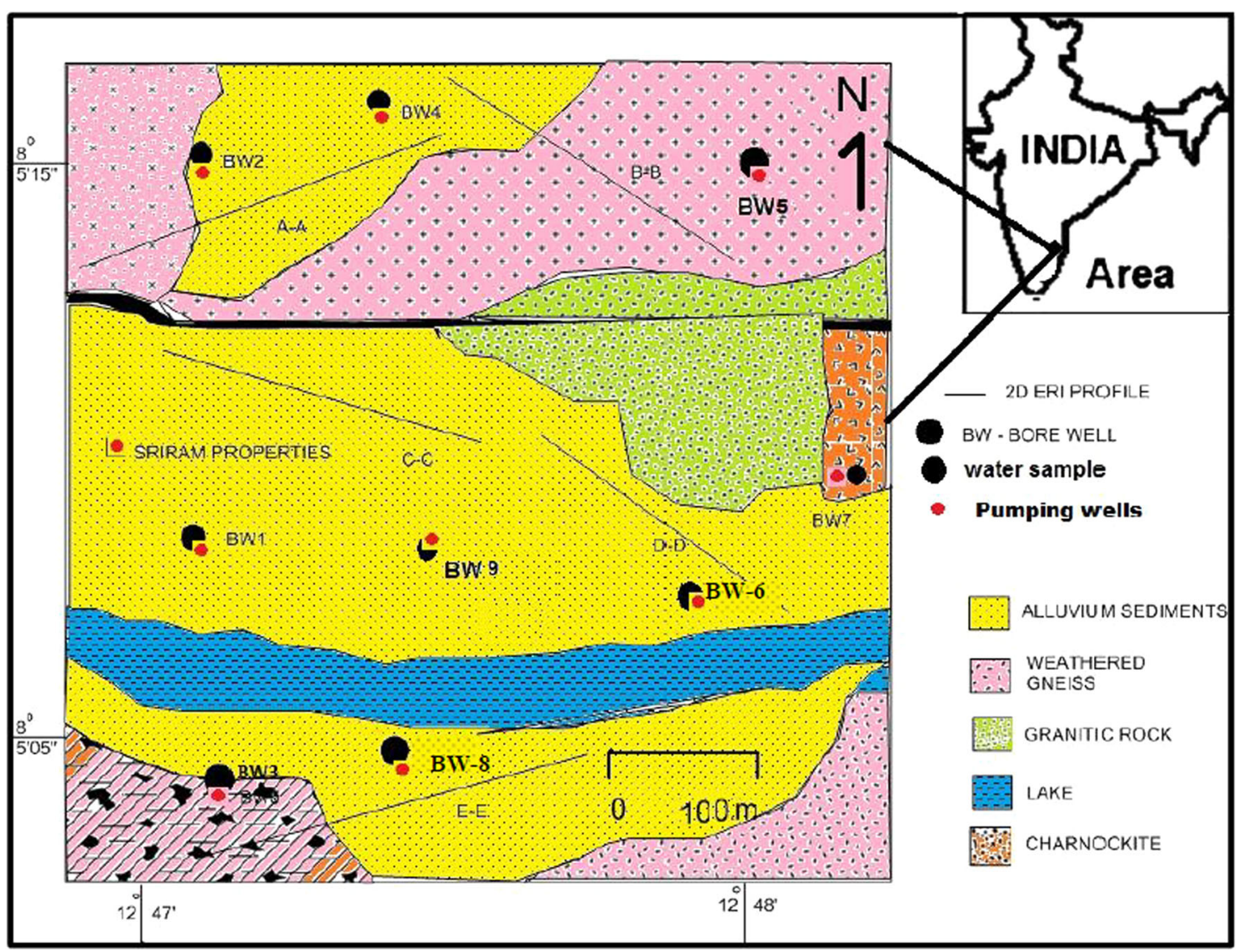

Fig. 1 Location map of the study area in and around Perumattunallur lake, Southern India

Fig. 2 Showing

a Perumattunallur lake,

Southern India, $\mathbf{b}$ a bank of the lake, c WTS-4 imaging system, and $\mathbf{d}$ Open well cutting for the geological formations
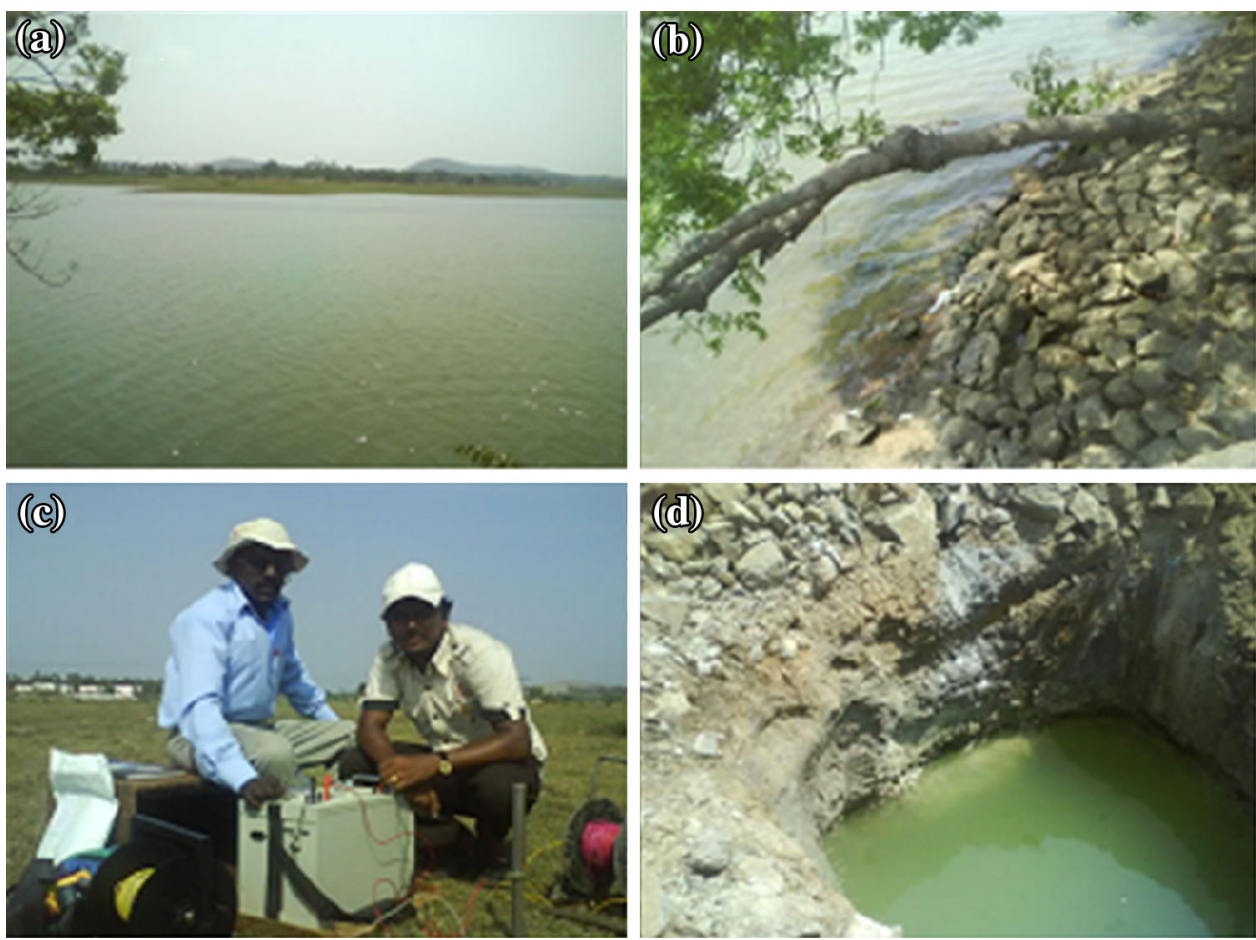


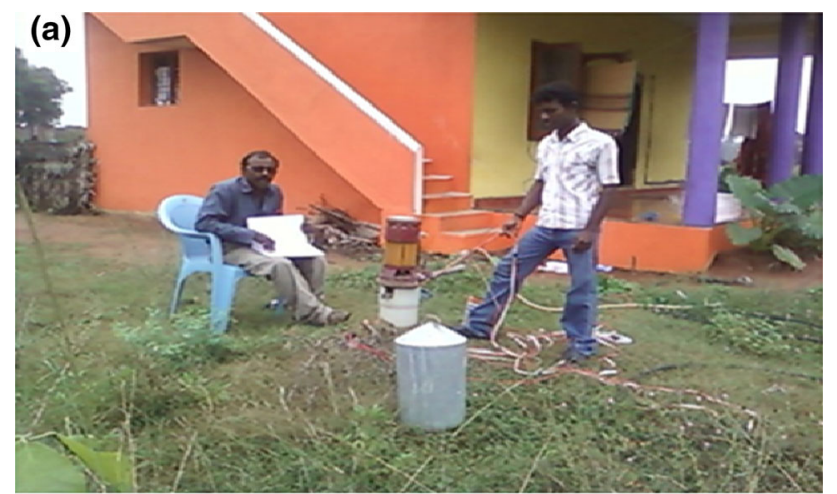

(b) Bw1

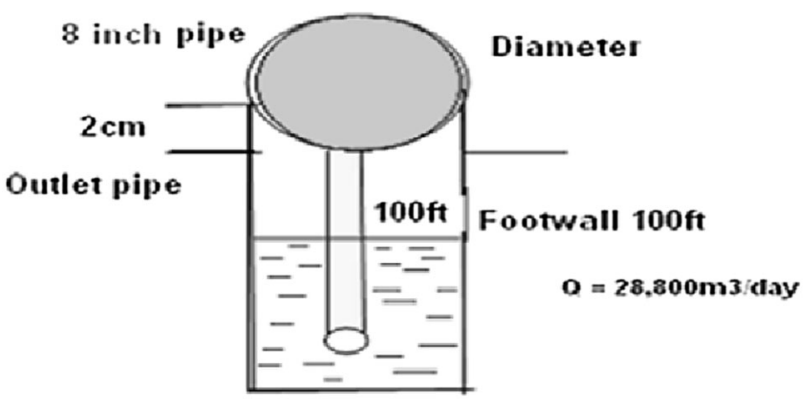

Fig. 3 Showing a pumping test data collection in the bore well at Karantha Puthuncherri, and $\mathbf{b}$ bore configuration

\section{Hydrochemical investigation}

The groundwater sample analysis is an important part to investigate the chemical constituents change in groundwater (Edet and Okereke 2001). The quality of groundwater was used for the future planning of cultivation. A total of 18 groundwater samples (Fig. 1) were collected in a $1 \mathrm{~L}$ bottle from the 9 boreholes (depth range: $20-120 \mathrm{~m}$, bgl) for two different seasons (i.e., pre- and post-monsoons) during January 2012 and July 2012, respectively; and it was sealed tightly. The samples were analyzed for $\mathrm{Ca}^{2+}, \mathrm{Mg}^{2+}, \mathrm{Na}^{+}, \mathrm{K}^{+}, \mathrm{HCO}_{3}{ }^{-}, \mathrm{Cl}^{-}, \mathrm{SO}_{4}{ }^{2-}, \mathrm{PO}_{4}{ }^{-}$, $\mathrm{H}_{2} \mathrm{SiO}_{4}, \mathrm{~F}^{-}, \mathrm{pH}$, and TDS using standard procedures
(American Public Health Association (APHA) 1985). The $\mathrm{pH}$ and TDS were measured by Systronics Water Quality Analyzer. $\mathrm{SO}_{4}{ }^{2-}, \mathrm{PO}_{4}$, and $\mathrm{H}_{4} \mathrm{SiO}_{4}$ were determined by digital spectrophotometer model GSS 700A (Electronic Corporation of India). The $\mathrm{Na}^{+}$and $\mathrm{K}^{+}$were determined using flame photometer (Systronics mk-1/mk-III). The $\mathrm{Ca}^{2+}, \mathrm{Mg}^{2+}, \mathrm{HCO}_{3}{ }^{-}$and $\mathrm{Cl}^{-}$were analyzed by titrimetric method. The charge balance calculated was generally $<10 \%$ confirming the reliability of the analytical results.

The hydrochemcial data were processed with the help of GIS software package (ArcGIS 9.3), as it is an immense platform for thematic layer preparation and mathematical calculations. The choice of this particular software is because of its varied features of storage, retrieval, mapping and analysis of geographic data. Spatial features can be stored in a coordinate system (latitude/longitude, state plane, UTM, etc.), which reference a particular place on the earth (Prasad et al. 2008). Also its specialty in associating spatial features with descriptive attributes in tabular form and these in the same coordinate system can then be layered together for mapping and analysis. It helps in decreasing the tedious job. The 'Spatial Analyst Tools' from the extension tools of Arc catalog were used. The spatial distribution of hydrochemical parameters (mainly major cations and anions) was constructed by Kriging method. It is the best interpolation method in the ArcGIS Tools of extension. The interpolation method was used by Inverse Distance Weighted (IDW) to the extent of similarity. The vector maps of the hydrochemcial parameters were constructed for each parameter and they were then converted into raster form to reclassify by assigning suitable ratings based on their nature.

\section{Aquifer characterization}

The pumping test was conducted at the selected 7 sites (Fig. 1). A typical site is shown in Fig. 3a. It has about $8^{\prime \prime}$ outer pipe diameter and discharge rate is about
Fig. 4 2-D ERI section along $\mathrm{A}-\mathrm{A}^{\prime}$ in the study area

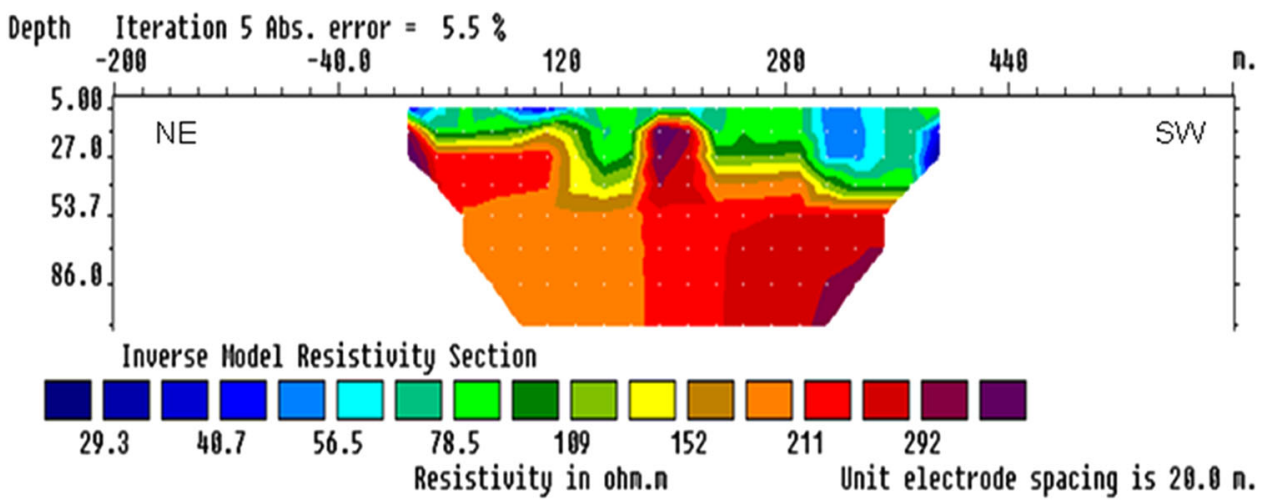


Fig. 5 2-D ERI section in B-B direction in the study area
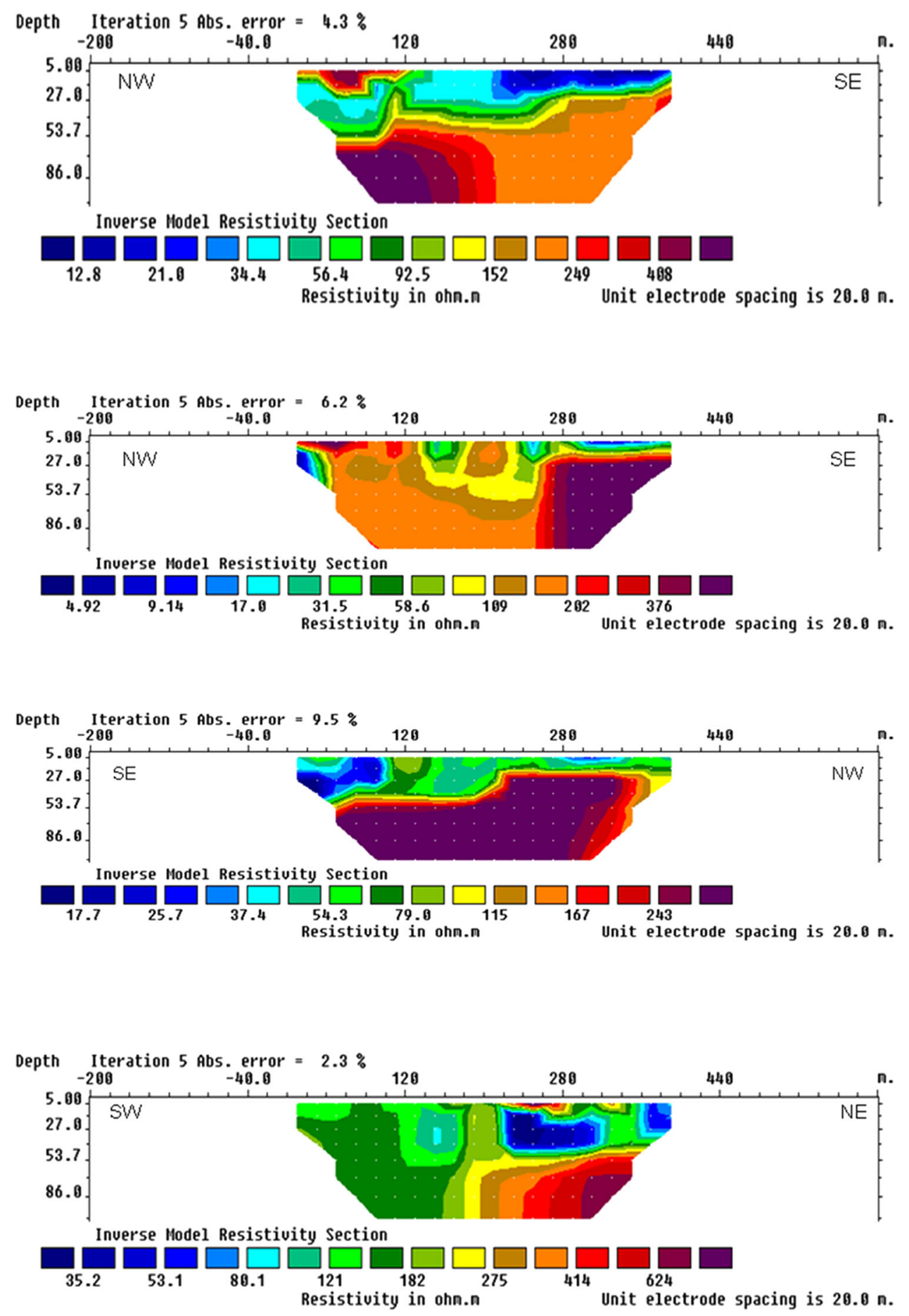

Resistivity in ohn.n
Fig. 8 2-D ERI section along $\mathrm{E}-\mathrm{E}^{\prime}$ in the study area
Fig. 6 2-D ERI section along $\mathrm{C}-\mathrm{C}^{\prime}$ direction in the study area

Fig. 7 2-D ERI section along $\mathrm{D}-\mathrm{D}^{\prime}$ direction in the study area
$28,800 \mathrm{~m}^{3} /$ day (Fig. 3b). The site is made up of clay, calcrete, gneiss and charnockite rock (Boulton 1970; Bangoy and Drogue 1994; Braun et al. 2009). The static water level, pumping level, drawdown and well yield were processed using an electric sounder (Birsoy and Summers 1980). The pumping tests had been conducted at the bore wells equipped $2 / 3 \mathrm{HP}$ pump sets continuously pumping about $2.5 \mathrm{~h}$ at seven sites (Figs. 1, 3). Thies's (1935) method was employed for interpretation. The Thies curve was prepared on a suitable log-log scale. The field data plot was placed on the type of the curve and best match between the type curve and data plot was obtained by approximately moving latter over the former, keeping coordinate axes strictly parallel to each other. 
Fig. 9 Lithological distribution along with resistivity attributes obtained nearby the ERI results
Fig. 10 Resistivity distribution $(\Omega \mathrm{m})$ of clay/calcrete deposits in the study area
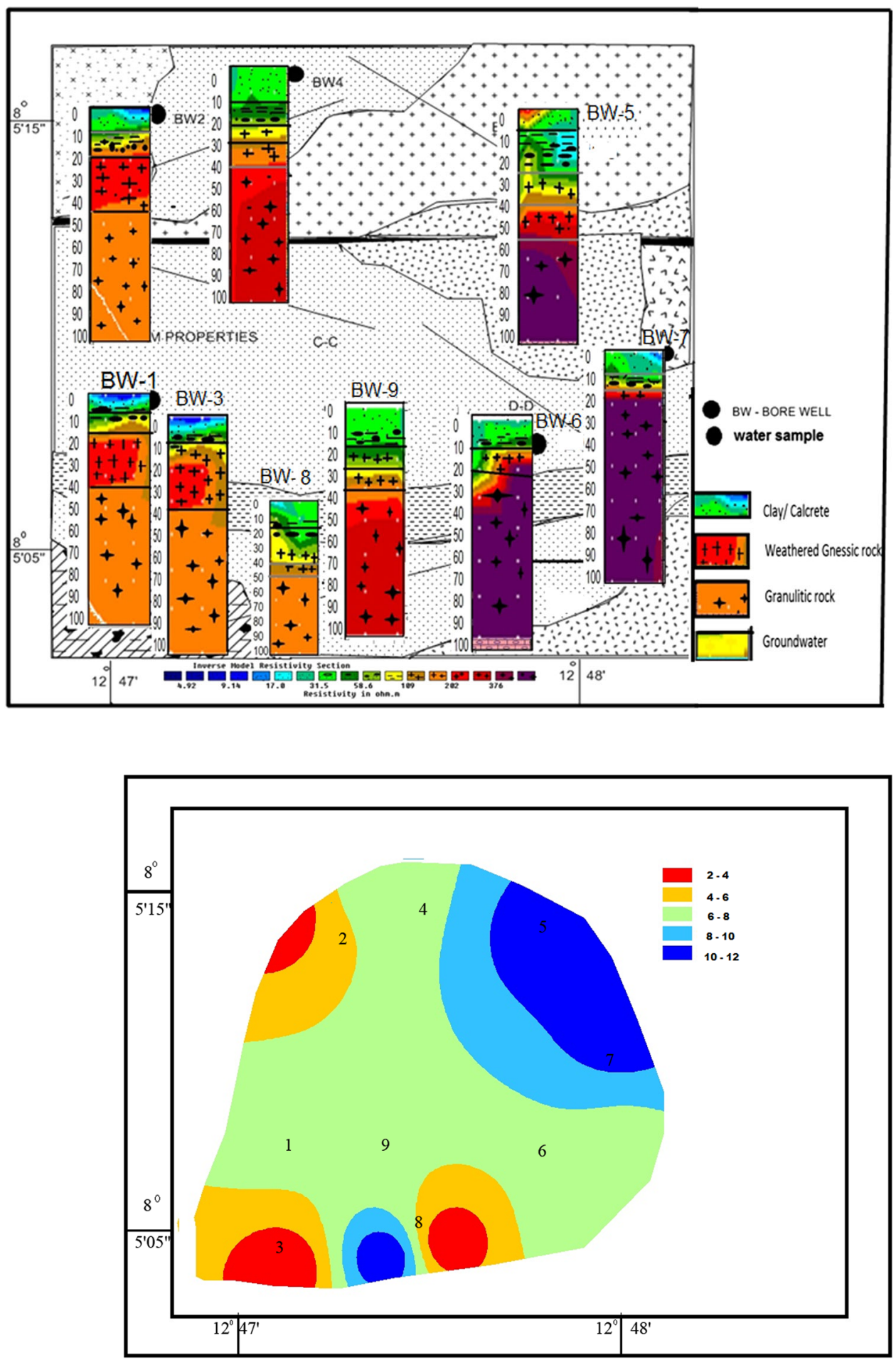

\section{Results and discussion}

\section{Geophysical studies}

For aquifer mapping, geoelectrical resistivity imaging studies were carried out at five sites. The 2-D ERI technique was used to target groundwater zones. The profiles' direction of resistivity imagings collected from $\mathrm{A}-\mathrm{A}^{\prime}, \mathrm{B}-\mathrm{B}^{\prime}, \mathrm{C}-\mathrm{C}^{\prime}$ and D-D' is in NE-SW, NW-SE, NW-SE, SE-NW and SW$\mathrm{NE}$ directions with a length of $400 \mathrm{~m}$. The collection of data was processed with the help of Res2D.INV software. The resistivity values for these profiles are discussed as below. 
Fig. 11 Resistivity distribution $(\Omega \mathrm{m})$ of weathered gneissic rock in the study area

Fig. 12 Resistivity distribution $(\Omega \mathrm{m})$ of deeper fractured genesis rock $(\Omega \mathrm{m})$ in the study area
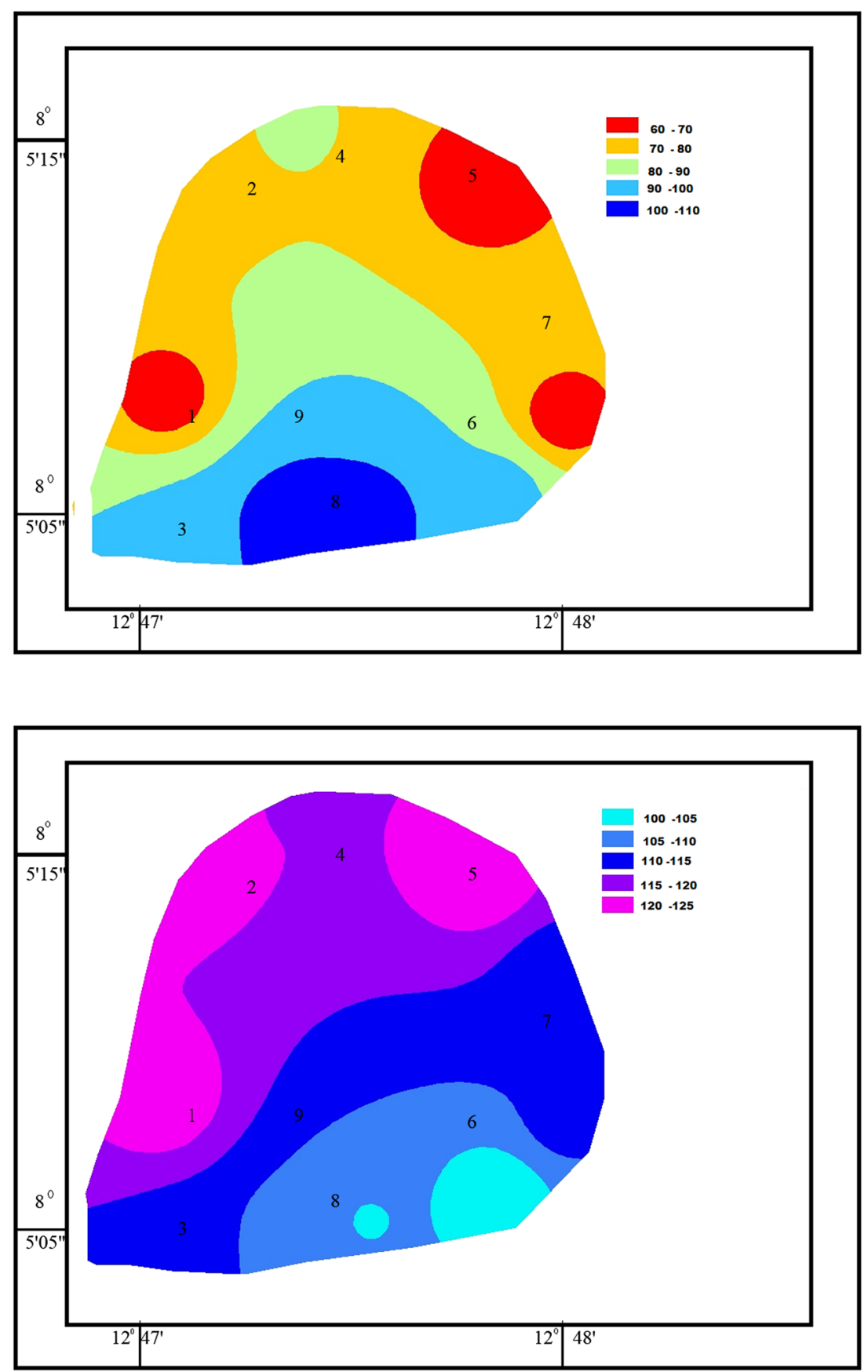

\section{The profile $A-A^{\prime}$}

The 2-D ERI subsection (Profile $A-A^{\prime}$ ) with a length of $400 \mathrm{~m}$ is up to a depth sounding of $100 \mathrm{~m}$. The true resistivity section demarcates alluvium deposits up to $5 \mathrm{~m}$ as the top layer with resistivity ranges between 40 and $295 \Omega \mathrm{m}$. The resistivity of intermediate-calcite layer varies from 40 to $109 \Omega \mathrm{m}$ along SW-NE trend. Weathered zone is identified at the top and fractured zones are confined to greater depths. Fractured zone/weathered gneissic rock of the aquifer is identified at depth of 5-53 $\mathrm{m}$ ranges of resistivity values from 109 to $152 \Omega \mathrm{m}$. Massive or fractured charnockite rock occurs from 50 to $100 \mathrm{~m}$ depth. The basin-like structure on the image indicates the high potential groundwater zone (Fig. 4).

The profile $B-B^{\prime}$

The profile $\mathrm{B}-\mathrm{B}^{\prime}$ profile direction is NW-SE trend. The top layer is covered by alluvium deposits with a resistivity 
Fig. 13 Resistivity distribution $(\Omega \mathrm{m})$ of massive charnockite rock in the study area

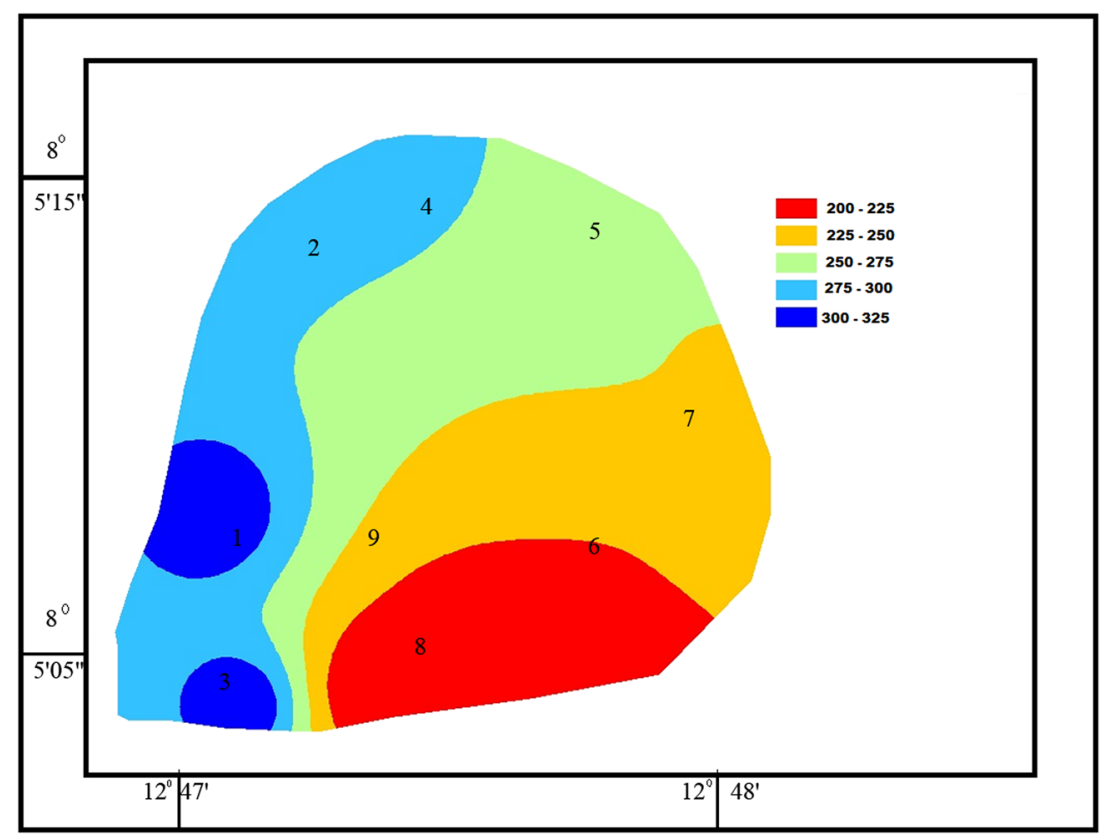

Fig. 14 Depth to gneissic rock $(\mathrm{m}, \mathrm{bgl})$ in the study area

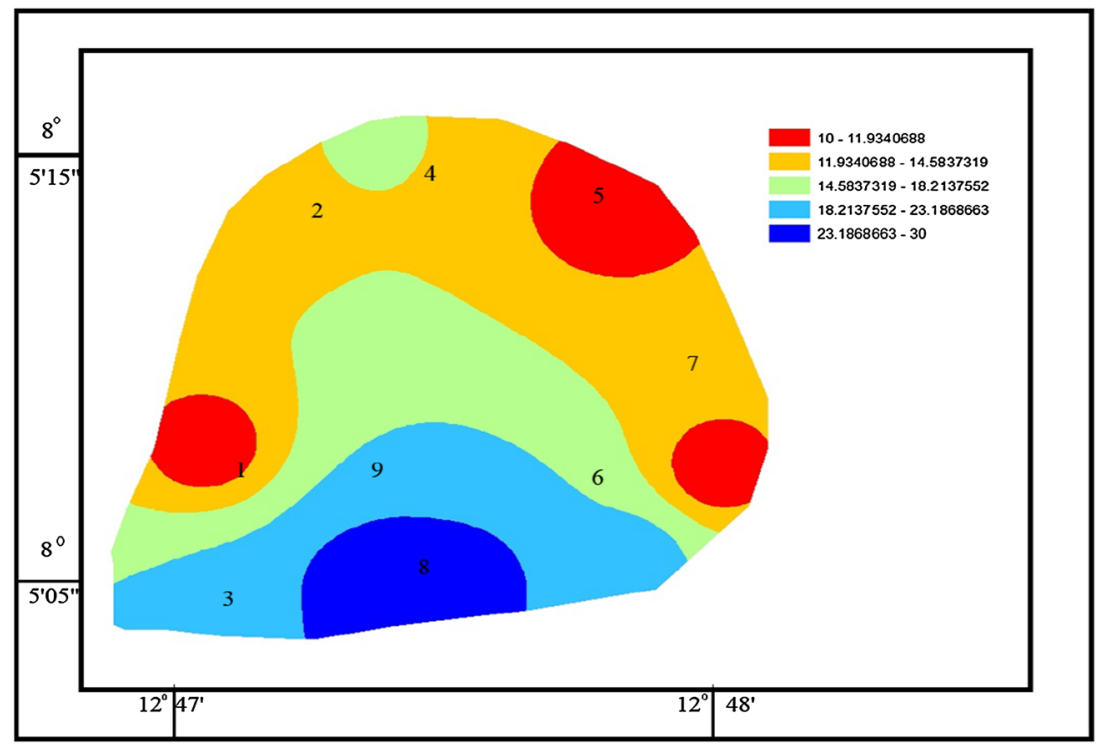

range of $21-128 \Omega \mathrm{m}$ up to $5 \mathrm{~m}$ depth. The resistivity of calcareous clay is around $34 \Omega \mathrm{m}$ and the resistivity range of weathered genesis rock is about $93-109 \Omega \mathrm{m}$ on this profile (Fig. 5). The high and compact charnockite rock has resistivity range of $249-408 \Omega \mathrm{m}$. The aquifer yield is high near the SE corner of the profile where the lake water is being discharged (Fig. 1).

\section{The profile $C-C^{\prime}$}

The profile 3 is oriented in NW-SE direction. The top layer contains clay is a range of resistivity of $10-492 \Omega \mathrm{m}$. The calcite occurs with resistivity range of $10-17 \Omega \mathrm{m}$. The weathered gneissic/fractured gneissic rocks are differentiated from resistivity between 58 and $200 \Omega \mathrm{m}$. Groundwater zone is identified with the range of resistivity from 120 to $200 \Omega \mathrm{m}$ which occurs up to a depth of $60 \mathrm{~m}$ depth (Fig. 6).

\section{The profile $D-D^{\prime}$}

The SE corner of the profile 4 is fully recharged with lake water. The range of resistivity encountered about 18-37 $\Omega$ $\mathrm{m}$ up to a depth of $60 \mathrm{~m}$. The genesis rock with 
Fig. 15 Depth to top of shallow freshwater aquifers $(\mathrm{m}, \mathrm{bgl})$ in the study area
Fig. 16 Depth to top of deeper fractured aquifers $(\mathrm{m}, \mathrm{bgl})$ in the study area
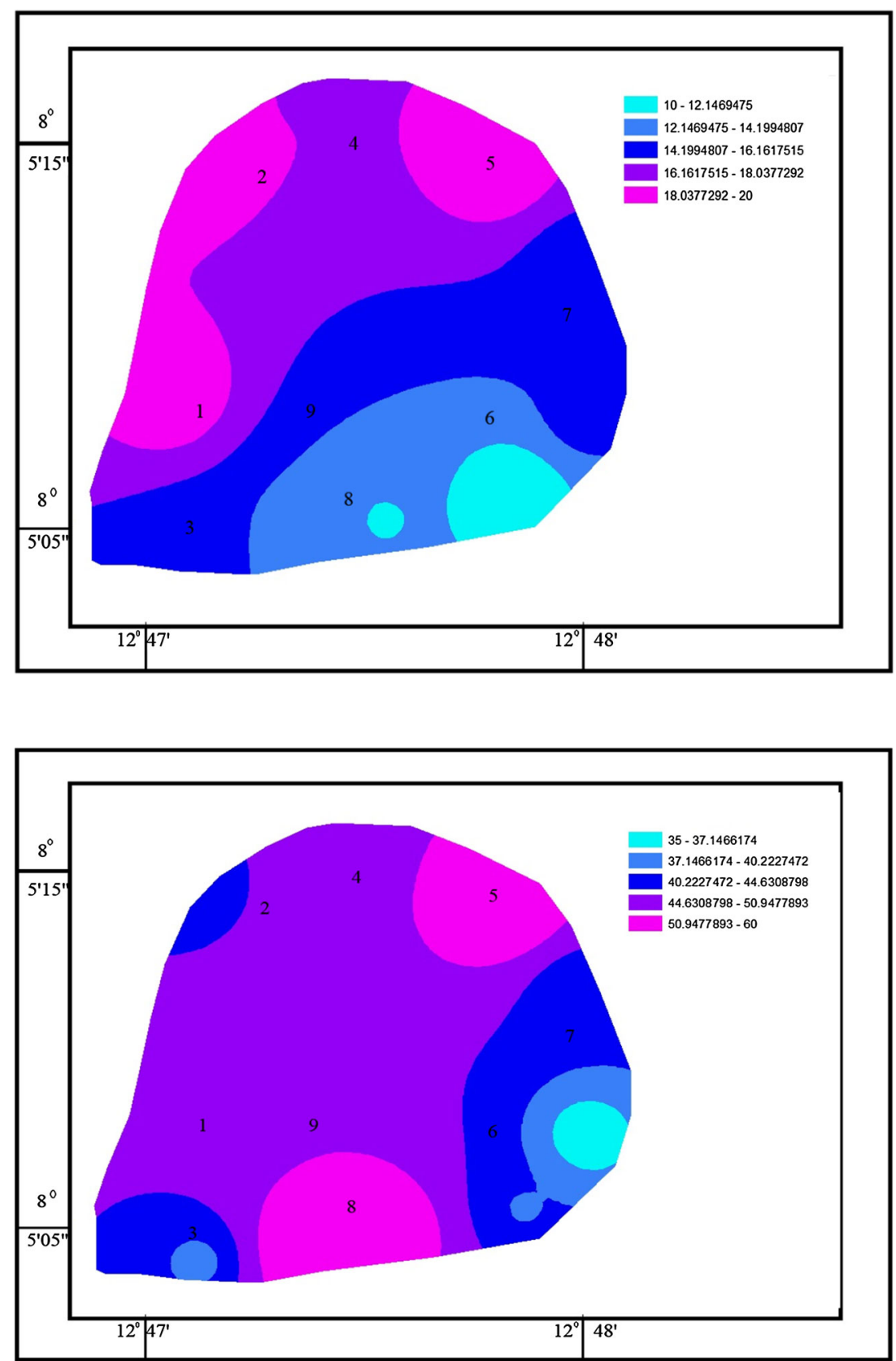

groundwater zone is identified through the resistivity range of 79-115 $\Omega-\mathrm{m}$ which is also compared with the borehole lithologs. The charnockite rock is an expose on this profile in the NW corner away from the lake side (Fig. 7).

\section{The profile $E-E^{\prime}$}

The profile 5 is in the direction of SW-NE direction. The aquifer zone is saturated with clay, calcrete and gneissic rocks. The resistivity of genesis rock ranges from 80 to $121 \Omega$-m at depth of $60 \mathrm{~m}$ (Fig. 8).
The ER Images of five sites were compared with the existing borehole lithologs and cross sections of nearby open wells confirmed the resistivity ranges of different subsurface geoelectrical layers (Figs. 9, 10).

1-12 $\Omega$ m: Top soil cover/clay/calcrete with kankar 10-20 $\Omega \mathrm{m}$ : Fine sand

10-120 $\Omega \mathrm{m}$ : Calcrete mixed gneissic rocks

60-110 $\Omega \mathrm{m}$ : Weathered gneissic rocks 100-125 $\Omega \mathrm{m}$ : Fractured gneissic rocks $>200 \Omega \mathrm{m}$ : Massive charnockite 

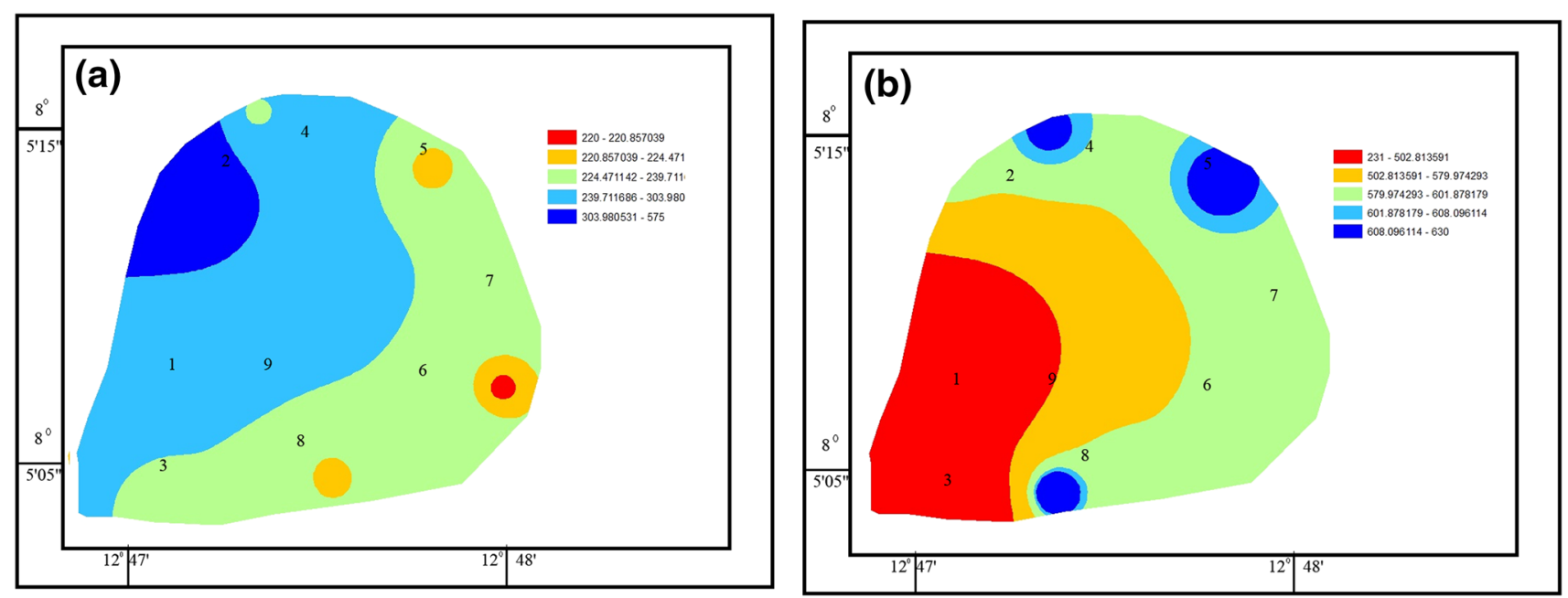

Fig. 17 TDS distribution in a pre-monsoon and b post-monsoon of year 2012
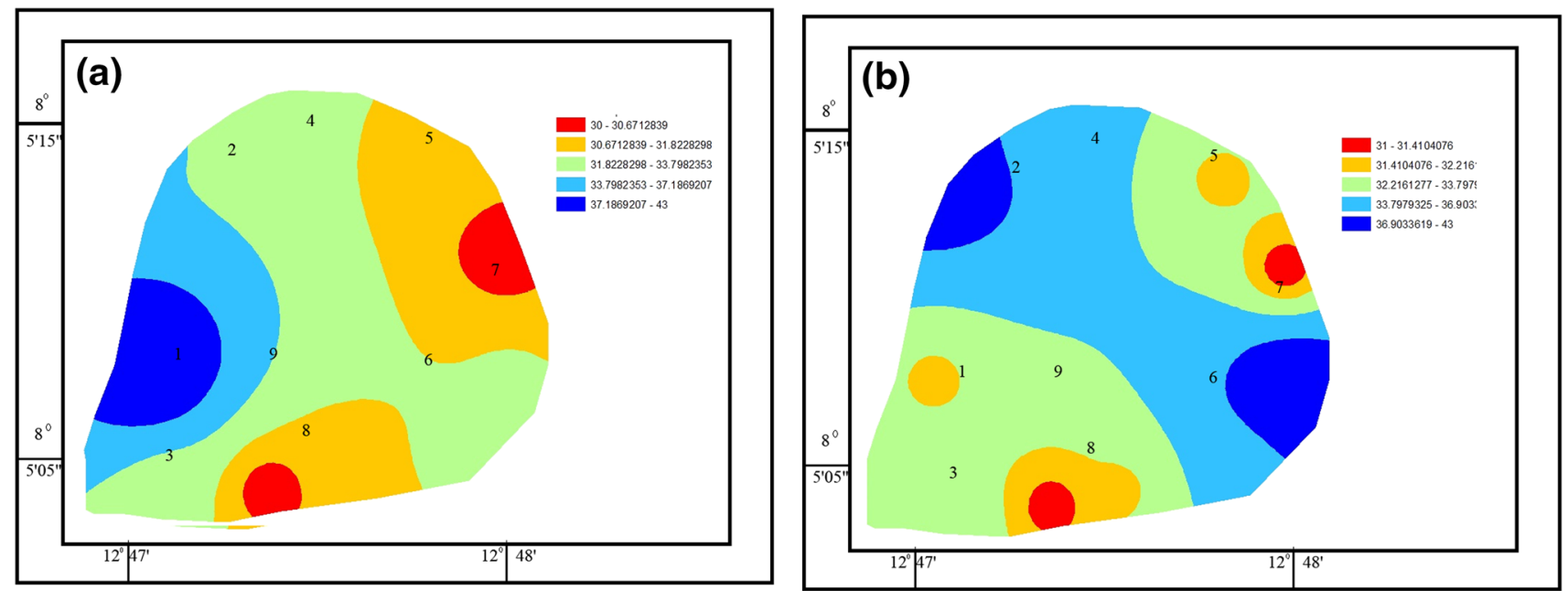

Fig. 18 Calcium distribution in a pre-monsoon and b post-monsoon of year 2012
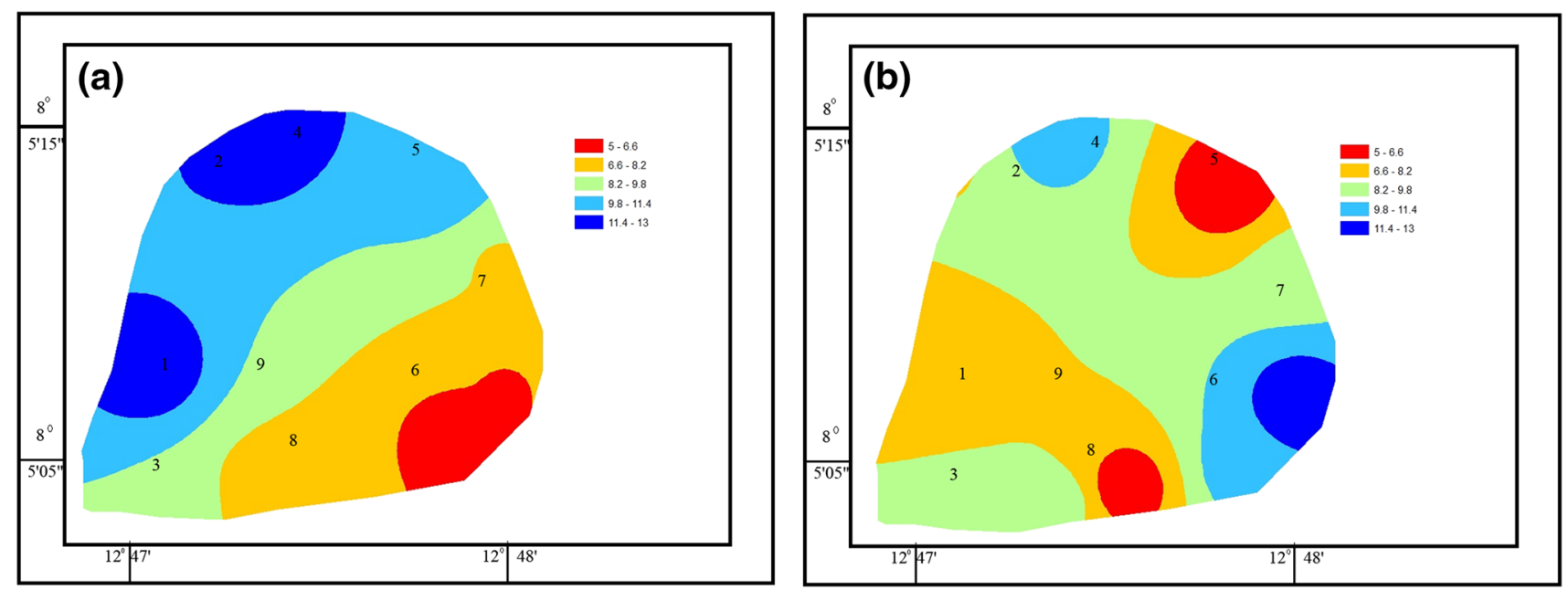

Fig. 19 Chloride distribution in a pre-monsoon and b post-monsoon of year 2012 

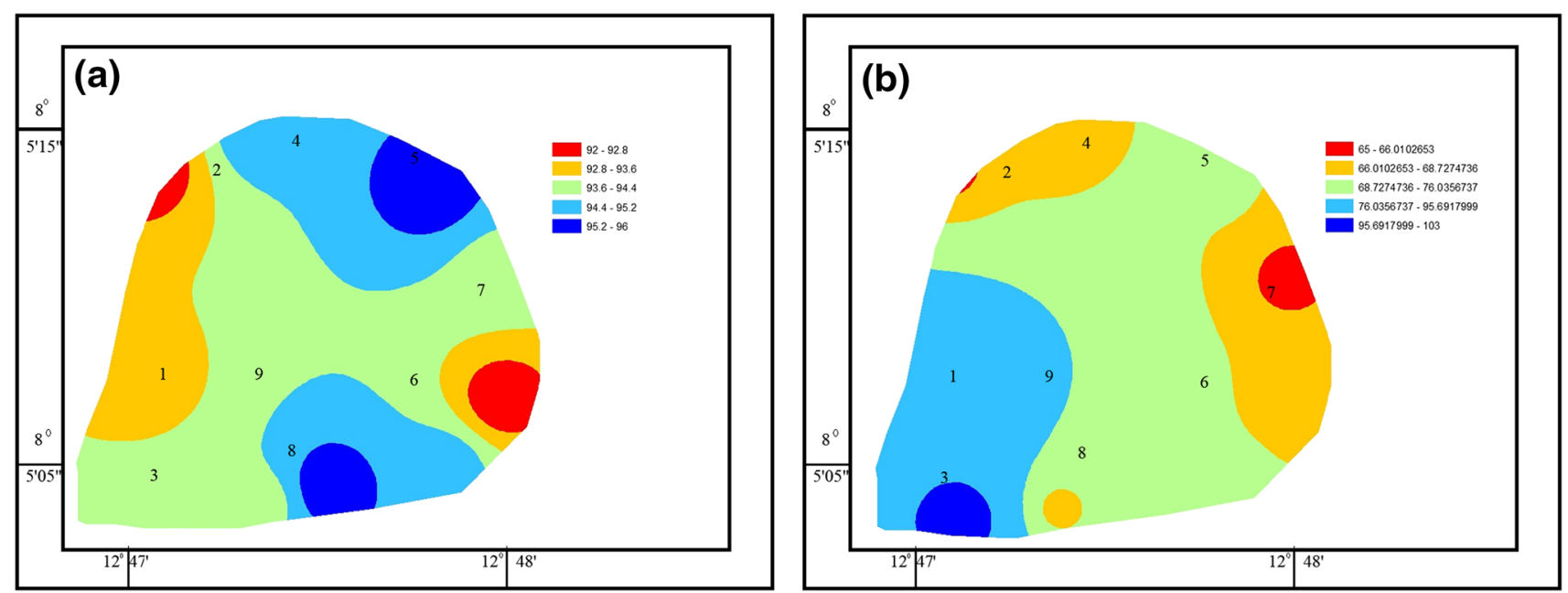

Fig. $20 \mathrm{HCO}_{3}{ }^{-}$distribution in a pre-monsoon and b post-monsoon of year 2012
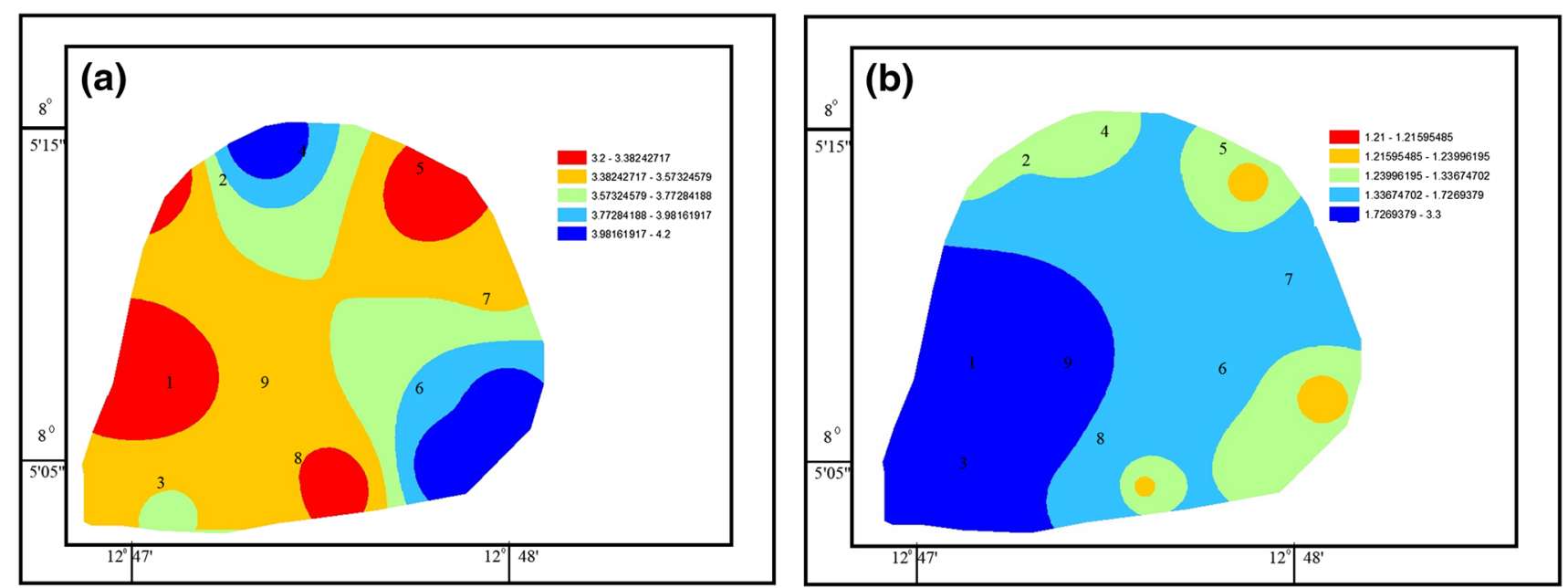

Fig. $21 \mathrm{~K}^{+}$distribution in a pre-monsoon and b post-monsoon of year 2012
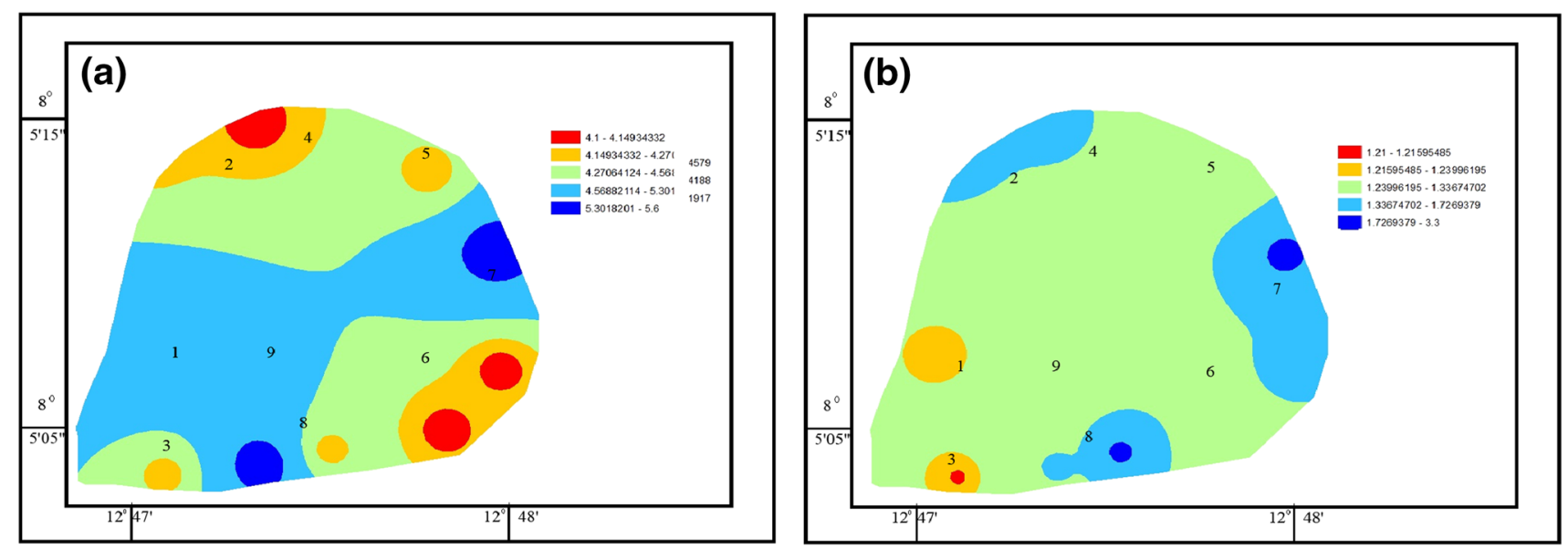

Fig. $22 \mathrm{Mg}^{2+}$ distribution in a pre-monsoon and b post-monsoon of year 2012 

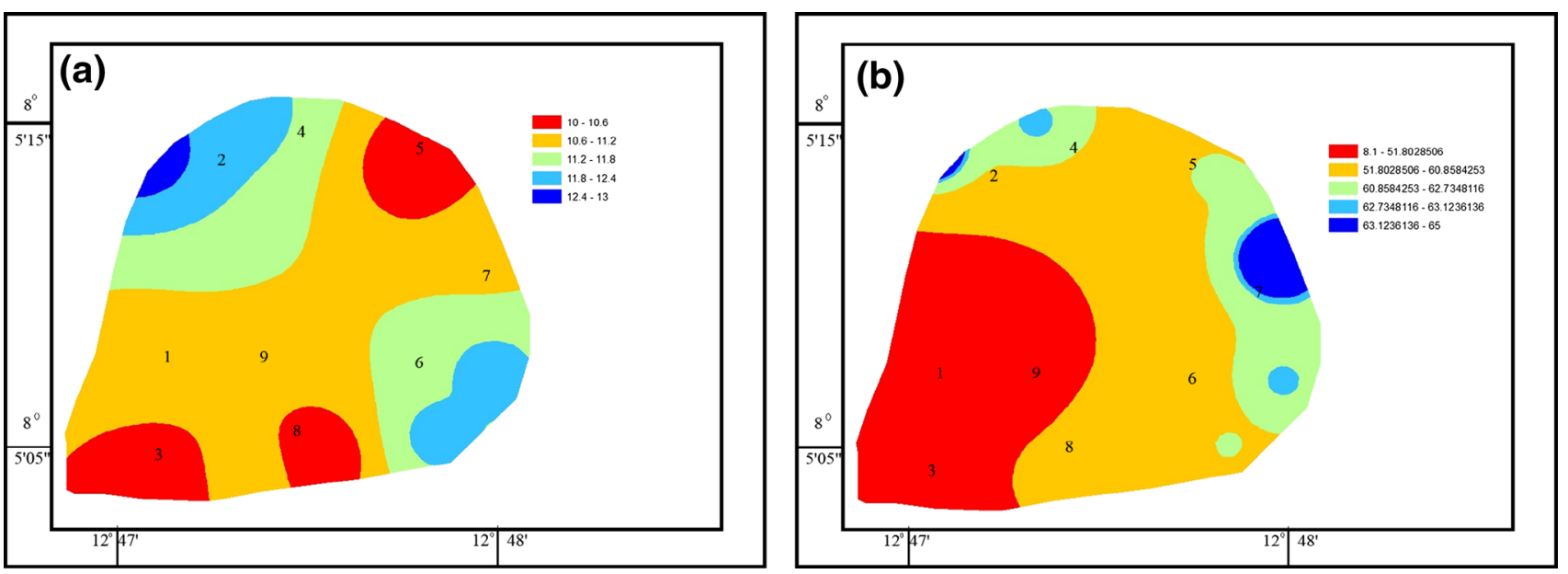

Fig. $23 \mathrm{Na}^{+}$distribution in a pre-monsoon and b post-monsoon of year 2012
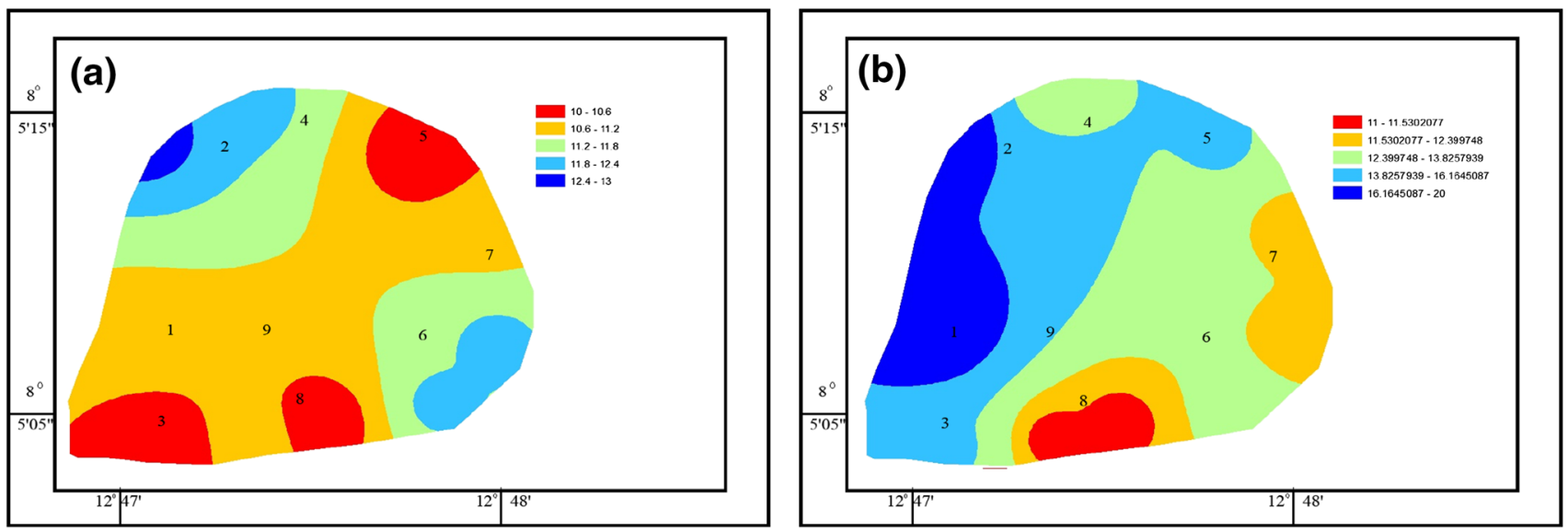

Fig. $24 \mathrm{SO}_{4}{ }^{-}$distribution in a pre-monsoon and $\mathbf{b}$ post-monsoon of year 2012

The resistivity distribution for weathered gneissic, gneissic and massive charnockite is shown in Figs. 11, 12 and 13. It indicates that comparatively low resistivity in the weathered zone was encountered in the northern part of the study area but the fracture gneissic and massive charnockite resistivities are comparatively more in this part. The geospatial distribution of layerwise change of clay and calcrete deposits has been determined by the range of resistivity $5-12 \Omega \mathrm{m}$. The distribution of clay is accumulated in the S and SW corner of study area (Fig. 10). The resistivity distribution of weathered gneissic rock has shown that it is lowering towards the north. It covers about half of the area less than $80 \Omega \mathrm{m}$ resistivity (Fig. 11). But the charnockite is encountered comparatively low resistivity in the SE corner of the study area (Fig. 13) at the shallower depth. The depth to gneissic rock varies from 10 to $30 \mathrm{~m}$, bgl (Fig. 14) whereas the shallow aquifer is encountered at a depth range of 10-20 m, bgl (Fig. 15). The groundwater level that occurred at deeper fracture zones varies from 35 to $60 \mathrm{~m}$, bgl (Fig. 16). The shallow basement of charnockite rock acts as a barrier to restrict the groundwater flow direction which is also supported by the distribution of depth to shallow fresh aquifer and water level at deeper fractured zones in the SE part of the study area (Figs. 15 and 16).

\section{Hydrochemical studies}

The major cations and anions in groundwater samples obtained for the pre-and post-monsoons are presented in Table 1. The cation concentrations of $\mathrm{Na}^{+}, \mathrm{Ca}^{2+}, \mathrm{Mg}^{2+}$, and $\mathrm{K}^{+}$ions range from 7 to 9, 30-45, 4.1-5.6 and $3.2-4.3 \mathrm{mg} / \mathrm{L}$ in the post-monsoon whereas they vary from 8.1 to $65,31-43,4.5-12.5$ and $1.21-3.3 \mathrm{mg} / \mathrm{L}$ in the postmonsoon period. The geospatial distribution of TDS (Fig. 17) in the groundwater of the study area during preand post-monsoon seasons clearly indicates that the natural 

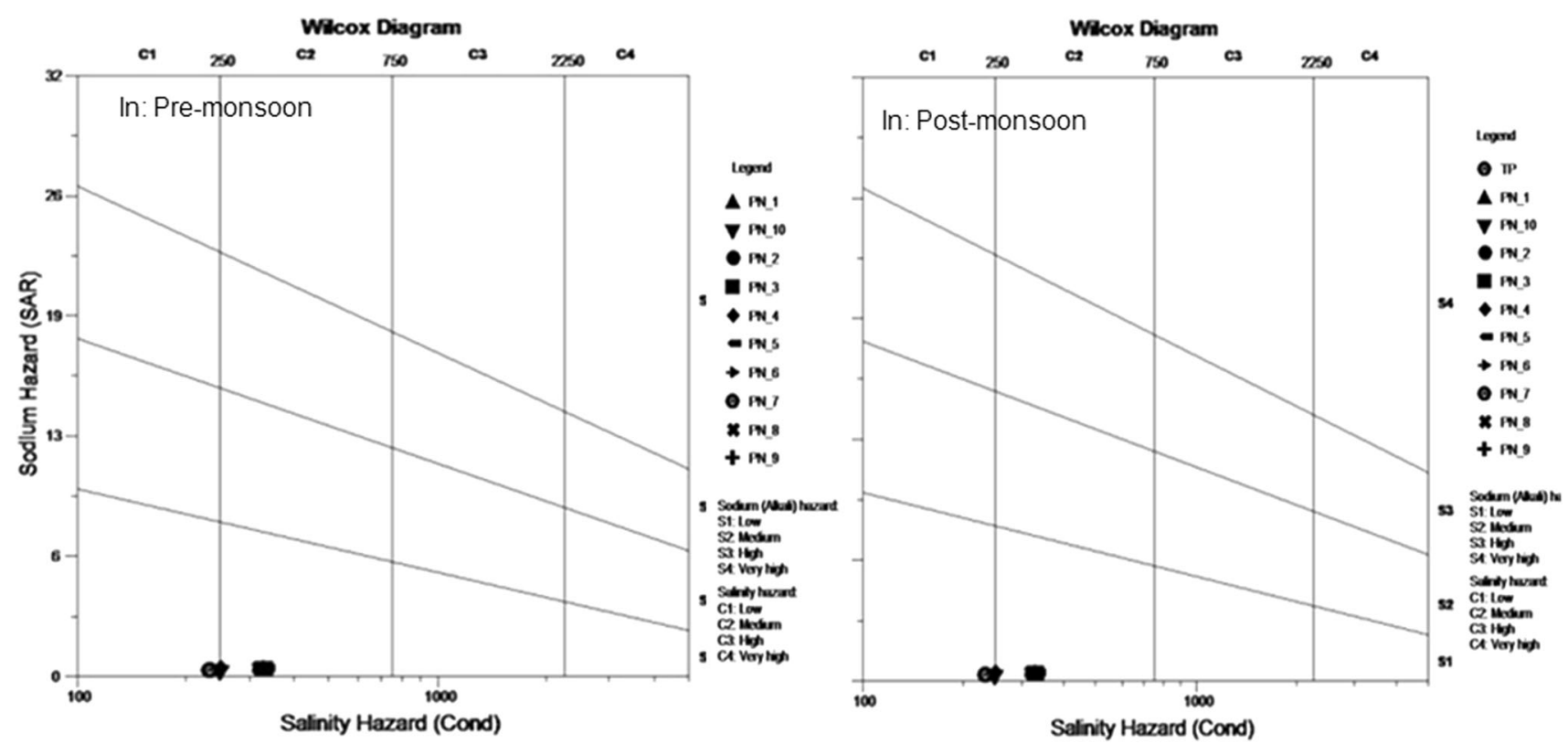

Fig. 25 Wilcox plot of groundwater quality for determining low, medium and high for agriculture purpose

Durov Plot

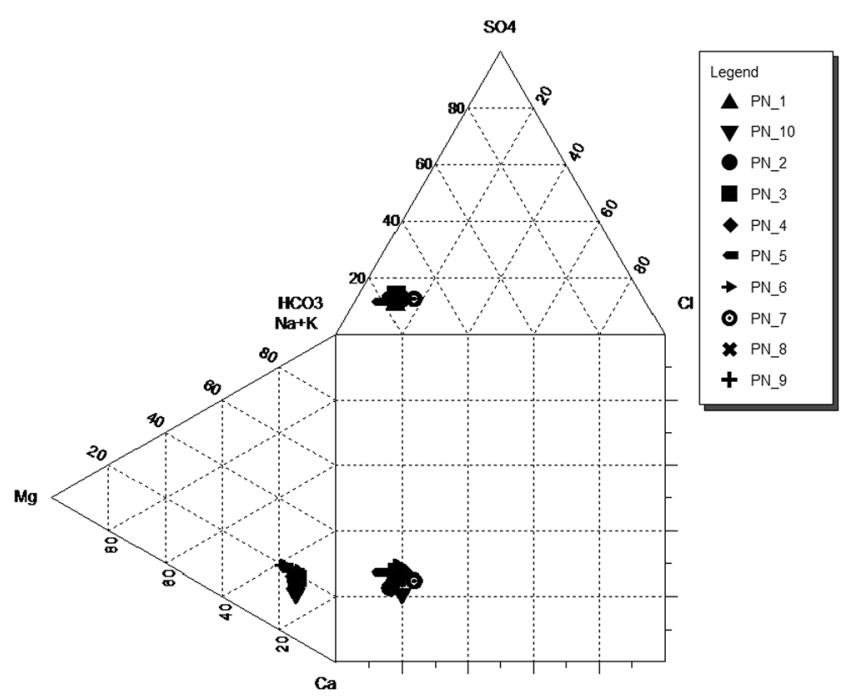

(a) in premonsoon

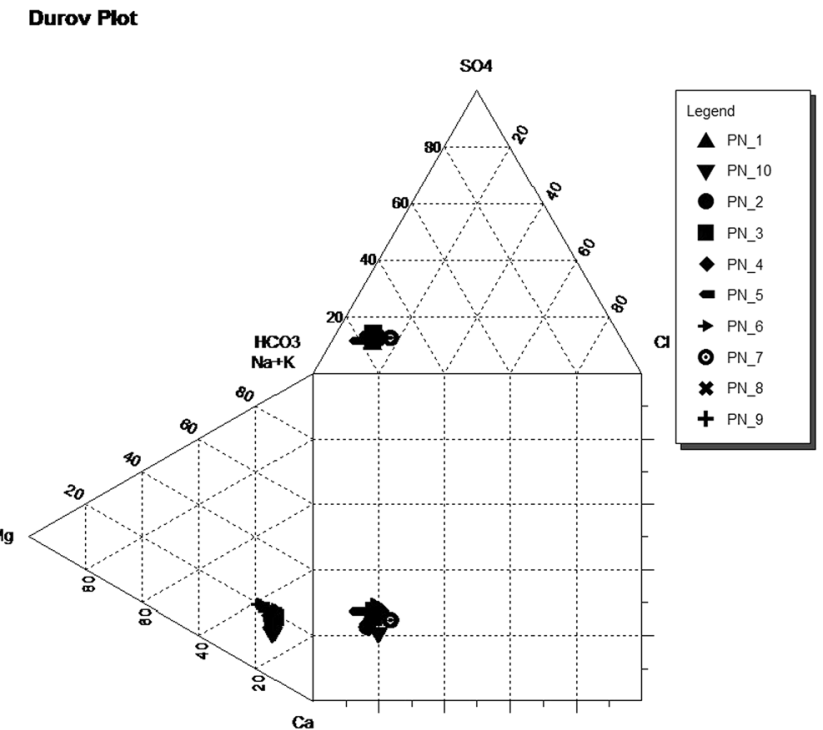

(b) in post monsoon

Fig. 26 Durov plot (1948) for saline water assessment in the study area

recharge with rainfall improved the groundwater quality and should be changed in the SE part of the study area.

The hydrochemical data were processed by the Aquachem Software. The average of $\mathrm{pH}: 7.03$ is acceptable in World Health Organization (1984) standard (pH: 7.0-8.0). The TDS values vary from 220 to $630 \mathrm{mg} / \mathrm{L}$ with an average of $306 \mathrm{mg} / \mathrm{L}$ in pre-monsoon and $523 \mathrm{mg} / \mathrm{L}$ in post-monsoon, respectively. The $\mathrm{Na}^{+}$values are minimum of $7-8.1 \mathrm{mg} / \mathrm{L}$ in pre-and post-monsoon periods, respectively. The $\mathrm{Mg}^{2+}$ ranges are $4.1-5.6 \mathrm{mg} / \mathrm{L}$ with an average of $4.6 \mathrm{mg} / \mathrm{L}$ in pre-monsoon. The $\mathrm{Ca}^{2+}$ is a range of low $30 \mathrm{mg} / \mathrm{L}$ to high $45 \mathrm{mg} / \mathrm{L}$ during the monitoring periods. Chloride is ranging from 1 to $13 \mathrm{mg} / \mathrm{L}$ in both the seasons.

Geographic information system is an effective tool for geospatial analysis of hydrochemical parameters (Selvam et al. 2014). Hydrochemical mapping was used for the aquifer quality study. The GIS geospatial analysis of water 


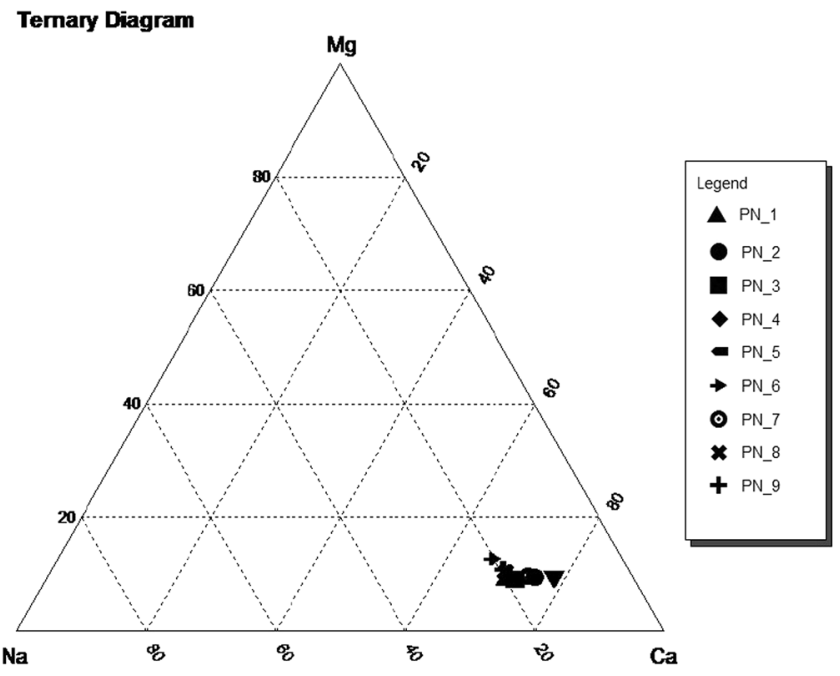

(a) In Pre-monsoon

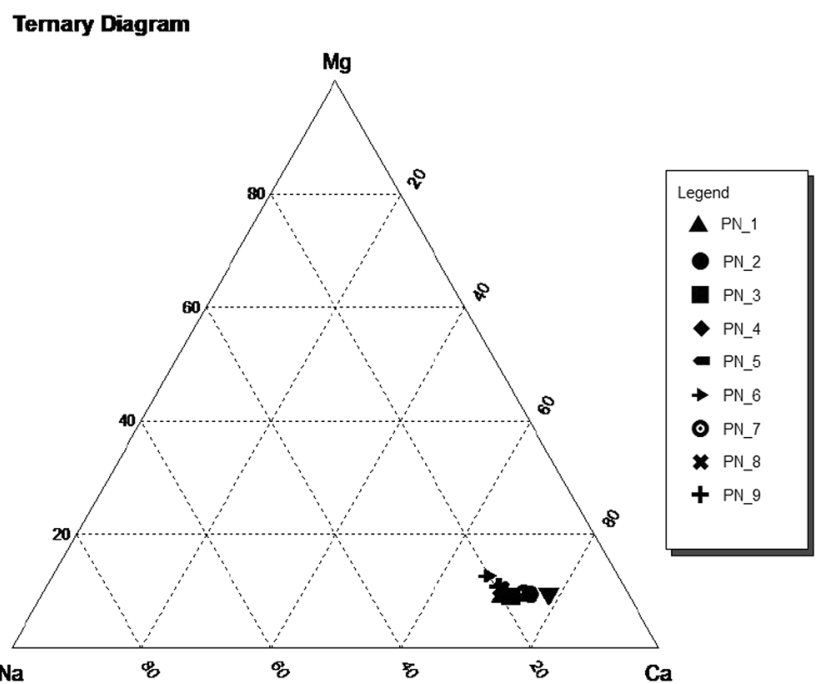

(b) In post-monsoon

Fig. 27 Ternary diagram for groundwater quality in the year 2012

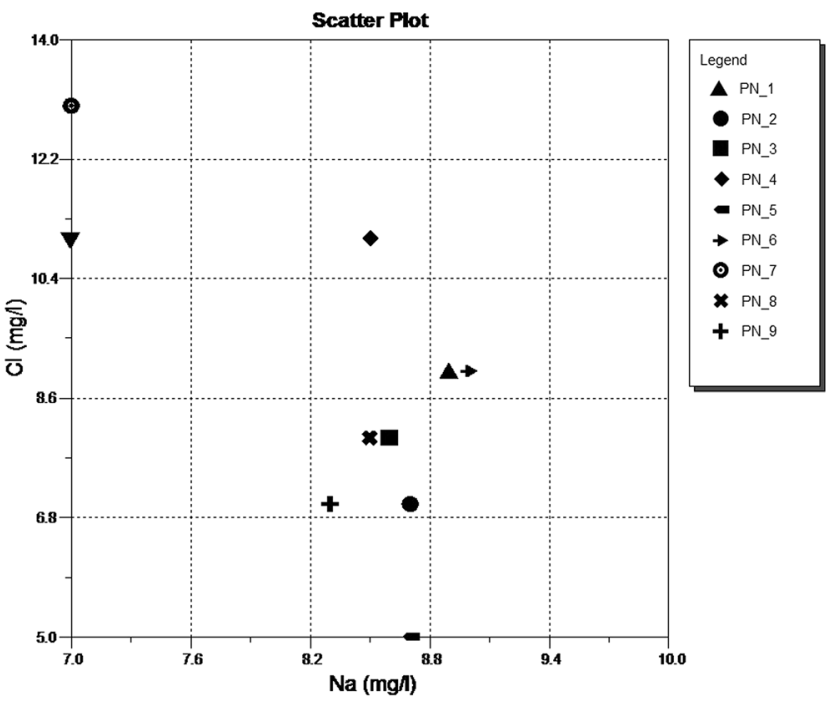

(a) In pre-monsoon

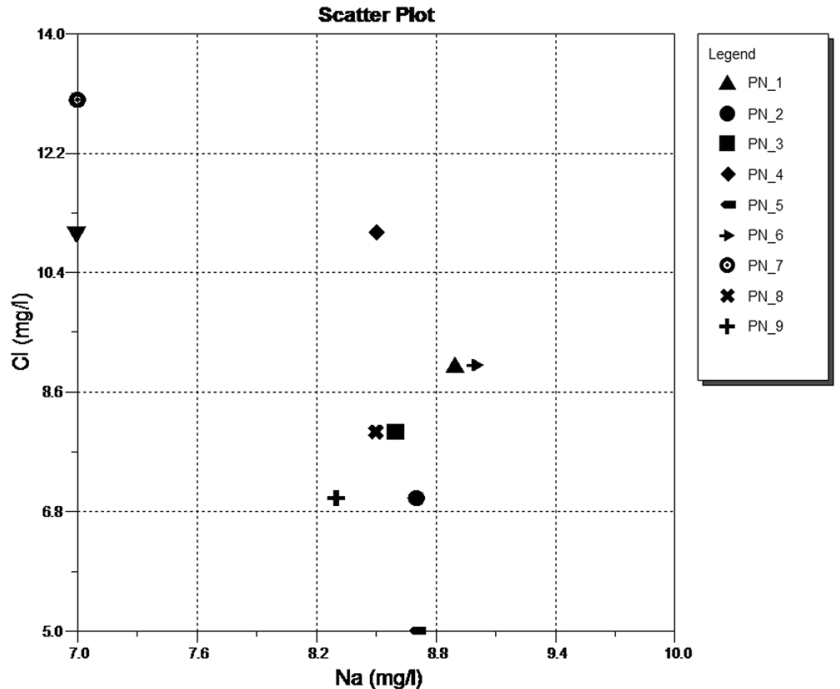

(b) In Post-monsoon

Fig. 28 Scatter plot for $\mathrm{Na}^{+}$versus $\mathrm{Cl}^{-}$for a pre-monsoon and b post-monsoon in the year 2012

quality data was utilized in the chemical mapping of all cations and anions including TDS which are shown in Figs. 17, 18, 19, 20, 21, 22, 23 and 24. Geospatial distribution of $\mathrm{Ca}^{2+}$ concentration in post-monsoon and premonsoon varies in NW and SW directions (Fig. 18). The $\mathrm{Cl}^{-}$values in both monsoons show no abnormal changes in the lake directions (Fig. 19). The high $\mathrm{Cl}^{-}$intake high tolerance limits in plants developing symptoms like leaf burn and leaf tissues. The EC distribution in NW-SE directions is due to the high thickness of clay deposits. The $\mathrm{HCO}_{3}{ }^{-}$distribution in post-monsoon is much higher in pre-monsoon (Fig. 20). The variation of values is due to the dissolution of carbonate and silicate minerals. The range of value of $\mathrm{K}^{+}$is from 1.2 to $4.3 \mathrm{mg} / \mathrm{L}$ which is derived from K-feldspar (Fig. 21). The $\mathrm{Mg}^{2+}$ concentration of groundwater is not slightly varied from post-monsoon to pre-monsoon (Fig. 22). It has not affected the crop yield. The $\mathrm{Na}^{+}$presence in the area is less concentrated in premonsoon (Fig. 23). But the $\mathrm{pH}$ concentration is not drastically changed from pre-monsoon to post-monsoon. The groundwater $\mathrm{pH}$ slightly varies in the period of pre-monsoon to post-monsoon. The spatial distribution of TDS, $\mathrm{Na}^{+}, \mathrm{K}^{+}, \mathrm{Ca}^{2+}, \mathrm{Mg}^{2+}, \mathrm{Cl}^{-}, \mathrm{SO}_{4}{ }^{2-}$, and $\mathrm{HCO}_{3}{ }^{-}$was plotted with the use of GIS geospatial tool. From this study, the groundwater of quality is very good and used for agricultural and domestic purposes in the study area. 

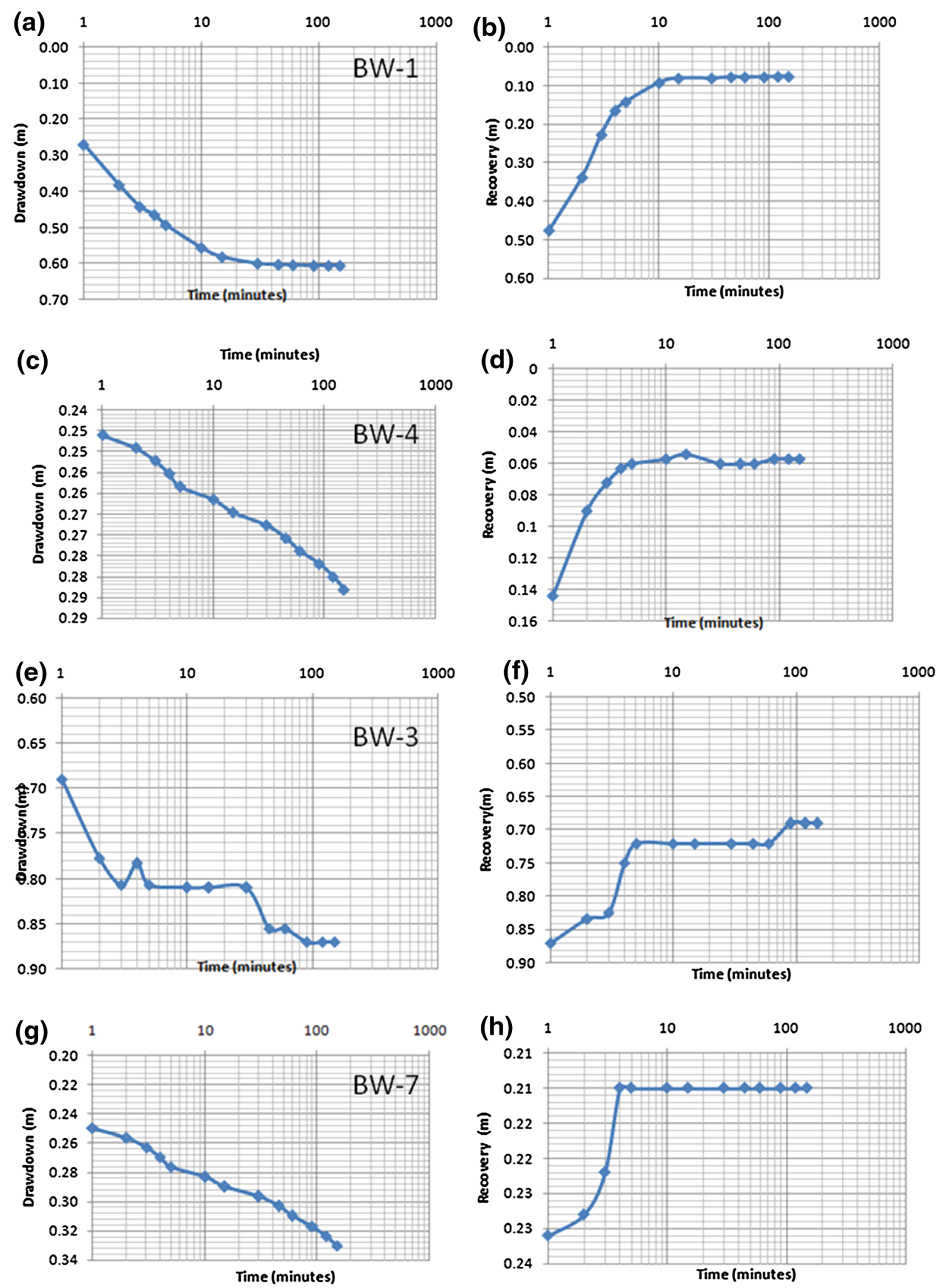

Fig. 29 Drawdown and recovery curves at BW-1 (Shiram Shagari-1), BW-4 (Karantha Puthancherry), BW-3 (Kumuzhli) and BW-7 (Shriram Shagari-2) around Perumattunallur lake, Southern India 
Table 1 Minimum, maximum, mean and standard deviation (SD) of groundwater samples around Perumattunallur lake, Southern India

\begin{tabular}{|c|c|c|c|c|c|c|c|c|}
\hline \multirow[t]{3}{*}{ Parameters } & \multicolumn{8}{|l|}{ Periods } \\
\hline & \multicolumn{4}{|c|}{ Pre-monsoon in January 2012} & \multicolumn{4}{|c|}{ Post-monsoon in July 2012} \\
\hline & Minimum & Maximum & Mean & SD & Minimum & Maximum & Mean & SD \\
\hline Temperature & 27.0 & 29.7 & 27.4 & 0.89 & 27.0 & 29.1 & 27.3 & 0.75 \\
\hline TDS & 220 & 575 & 306 & 132 & 231 & 630 & 523 & 159 \\
\hline $\mathrm{pH}$ & 6.91 & 7.29 & 7.03 & 0.75 & 7.23 & 7.75 & 7.62 & 0.78 \\
\hline $\mathrm{Na}^{+}$ & 7 & 9 & 8.32 & 0.72 & 8.1 & 65 & 51.54 & 22.90 \\
\hline $\mathrm{K}^{+}$ & 3.2 & 4.3 & 3.58 & 0.45 & 1.21 & 3.3 & 1.68 & 0.83 \\
\hline $\mathrm{Ca}^{2+}$ & 30 & 45 & 34 & 5.41 & 31 & 43 & 34.5 & 4.60 \\
\hline $\mathrm{Mg}^{2+}$ & 4.1 & 5.6 & 4.6 & 0.57 & 4.5 & 12.5 & 10.42 & 3.13 \\
\hline $\mathrm{Cl}^{-}$ & 5 & 13 & 8.8 & 2.34 & 1 & 12 & 5.21 & 5.39 \\
\hline $\mathrm{SO}_{4}{ }^{2-}$ & 10 & 13 & 11.5 & 1.08 & 11 & 20 & 13.9 & 3.14 \\
\hline $\mathrm{HCO}_{3}{ }^{-}$ & 90 & 101 & 93.8 & 3.11 & 65 & 103 & 73.6 & 13.59 \\
\hline
\end{tabular}

All ions: in mg/L, EC: $\mu \mathrm{S} / \mathrm{cm}$ at $20{ }^{\circ} \mathrm{C}, \mathrm{pH}=-\log _{10} \mathrm{H}^{+}$

Table 2 Estimated aquifer yields during summer and winter seasons

\begin{tabular}{lllll}
\hline S. no. & Bore well nos. & Village name $(\mathrm{s})$ & Yield value $\left(\mathrm{m}^{3} /\right.$ day $)$ in summer & Yield value $\left(\mathrm{m}^{3} /\right.$ day) in winter \\
\hline 1 & BW-1 & Shiram Shagari-1 & 259.2 & 316.8 \\
2 & BW-2 & Shiram Shagari-2 & 252.0 & 302.4 \\
3 & BW-4 & Karantha Puthancherry & 244.8 & 316.8 \\
4 & BW-5 & Katturani & 252.0 & 316.8 \\
5 & BW-3 & Kumuzhli & 230.4 & 302.4 \\
6 & BW-8 & Kanivagam & 237.6 & 302.4 \\
7 & BW-7 & Shiram Shagari-2 & 244.8 & 316.8 \\
Average & & & 245.8 & 310.6 \\
\hline
\end{tabular}

For the salinity hazards in the study area, Wilcox diagram (Wilcox 1955) is displayed in Fig. 25. The sodium absorption ratio (SAR) of 250-270 is used for agriculture. From the geochemical mapping, the two types of rockwater interaction are identified like $\mathrm{CaO}$ (at $\mathrm{BW}$ four samples) and $\mathrm{CaCO}_{3}$ types (at $\mathrm{BW}$ five samples). The Total Hardness (TH) of water is mainly based on the precipitation of calcium and calcium carbonate of these irons expressed as $\mathrm{mg} / \mathrm{L}$ of $\mathrm{CaCO}_{3}$. The hydrochemical sample data exceed the guideline values of World Health Organization (1984). The Wilcox plot diagram is used to determine the values of both monsoons low, moderate, high, and very high categories. The water samples (at BW nos 1, 2, 4, 6, 7 and 9) in both the monsoons are in the category of low salinity hazardous zone in the study area. The remaining samples (at BW nos. 3, 5 and 8) are located in the category of medium grade salinity hazardous zone.

Durov (1948) plot is used for the saline water domination in the fresh water region (Fig. 26). The concentrations of $\mathrm{Ca}^{2+}, \mathrm{Mg}^{2+}, \mathrm{Cl}^{-}, \mathrm{HCO}_{3}{ }^{2+}, \mathrm{Na}^{+}+\mathrm{K}^{+}, \mathrm{SO}_{4}{ }^{2-}$ are taken into account of diagrammatic representation. Most of the samples on the Durov plot represent in both monsoons giving an equal distribution of salinity balance due to the lake water saturation. The ternary plots of the groundwater samples for pre- and post-monsoons reflect that the $\mathrm{Ca}^{2+}$ concentration in all groundwater samples is due to weathering and precipitation (Fig. 27). But the scatter plots of $\mathrm{Na}^{+}$versus $\mathrm{Cl}^{-}$ratios in both periods have determined the water quality distribution due to rock weathering clay siltation which is shown in Fig. 28.

\section{Pumping test}

An attempt has been made while choosing the wells to have a representative of the clay, calcite and charnockite rocks, which have a major share in the study area. Bore wells are common and they were considered for aquifer parameter determination. From the borehole data, the clay and calcrete distribution are dominant factors due to the lake depositional environments. The pumping tests were carried out with the measurements of water level and discharge recharge rate at seven sites (Fig. 1). It was conducted at BW-1 (Shiram Shagari-1), BW-2, BW-3(Kumuzhli), BW-4 (Karantha Puthancherry), BW-5 (Katturani), BW-7(Shiram Shagari-2) 
and BW-8 (Kanivagam). Ideally, this pumping test should not be started before the already existing water level change in the aquifer is known including both long-term regional trends and short-term variations of the water level. The selected pumping test area is located near the Perumattunallur lake, a fault or simply lateral changes in lithology of the aquifer material. The recharge boundary is along in which there is comparative less drawdown. A recharge boundary exists where an aquifer is freely connected hydraulically to the lake, if an aquifer is tested near recharge steady state condition. For this, the drawdown and recovery curves at the selected wells are shown in Fig. 29. The aquifer yields occurring in an around the lake are very high. The high aquifer yield condition depends on the natural formation of the hilly region covered with alluvium deposits. In Summer, the aquifer yields vary from 244.8 to $259.2 \mathrm{~m}^{3} /$ day in the northern part of the lake, whereas in the southern part it varies from 230.4 to $237.6 \mathrm{~m}^{3} /$ day. The average water yield of the study area is about $245.8 \mathrm{~m}^{3} /$ day in summer, whereas $310.6 \mathrm{~m}^{3} /$ day in the winter season of the selected seven bore wells which are presented in Table 2.

\section{Conclusions}

The 2-D ERI technique is a useful technique to identify the fault and fractured zone for aquifer distribution. The true resistivity variation in shallow depth is from 1 to $12 \Omega-\mathrm{m}$ which acts as the top layer. It is followed by fine sand with a resistivity range of calcrete (10-20 $\Omega \mathrm{m})$ and calcrete mixed with gneissic rocks with resistivity range of $20-120 \Omega-\mathrm{m}$. The results of the 2-D ER Images and bore well lithologs are more or less an equal pattern of subsurface structural features. The pumping tests were conducted nearby the 2-D ERI sites used to estimate the potential of groundwater. The wells are located in weathered gneiss rock. Specific yield ranges from 230.4 to $316.8 \mathrm{~m}^{3} /$ day. The groundwater quality evaluation around the Perumattuanallur lake site using hydrochemical modeling could be used to provide safe drinking and agriculture water to farming community. The distribution of different chemical constituents at the lake site can be used as a variation in the alluvium, concrete and gneiss rock. Based on USSL classification around seven of the collected samples in C1S1 category, it indicates safe and marginal types for irrigation use. The groundwater is also good for irrigation with low alkalinity and moderate to high salinity hazard. The time duration drawdown interpretation of fall and flat curves determined the leaky artesian aquifer type curve. The well yield of groundwater is discharged from the lake leaky aquifer system through the faulted zone on the site. This study indicates that Perumattunallur village located nearby the lake site is good for paddy cultivation in the future.
Acknowledgments First author expresses his sincere thanks to Mr. A.P.C.V. Chockalingam, Secretary and Principal, V.O. Chidambaram College, Thoothukudi and The Director, CSIR-National Geophysical Research Institude, Hyderabad, and the helps extended by Shri Narayanan, Engineer, Geoenivirontech, Thoothukudi to carry out this work. The anonymous reviewer has suggested his constructive comments to improve the article. The authors are highly acknowledged to them.

\section{References}

Aizebeokhai AP (2010) 2D and 3D geoelectrical resistivity imaging: theory and field design. Sci Res Essays 5(23):3592-3605

American Public Health Association (APHA) (1985) Standard methods for the examination of water and waste, 16th edn. American Public Health Association, Washington, p 100

Antony Ravindran A (2013) Coastal-zone shallow-aquifer characterization study using geoelectrical and geochemical methods in zirconium complex, atomic energy, Pazhayakayal, Thoothukudi, India. Russ Geo Geophys 54:1529-1538

Bangoy LM, Drogue C (1994) Analysis of intermittent pumping tests in fissured fractal aquifers: theory and applications. J Hydrol 158(1-2):47-59

Birsoy YK, Summers WK (1980) Determination of aquifer parameters from step tests and intermittent pumping data. Ground Water 18(2):137-146

Boulton NS (1970) Analysis of data from pumping tests in unconfined anisotropic aquifers. J Hydrol 10:369-378

Braun JJ, Descloitres M, Riotte J, Fleury S, Barbiero L, Boeglin JL, Violette A, Lacarce E, Ruiz L, Sekhar M, Kumar MSM, Subramanian S, Dupree B (2009) Regolith mass balance inferred from combined mineralogical, geochemical and geophysical studies: mule Hole gneissic watershed, South India. Geochim Et Cosmochim Acta 73(4):935-961

Brutsaert W, Parlange MB (1998) Hydrological cycle explains the evaporation paradox. Nature 396:30

Döll P (2009) Vulnerability to the impact of climate change on renewable groundwater resources: a global-scale assessment. Environ Res Lett 4(035006):1010. doi:10.1088/1748-9326/4/3/ 035006

Dahlin T, Loke MH (1998) Resolution of 2D Wenner resistivity imaging as assessed by numerical modeling. J Appl Geophys 38:237-249

Deev EV, Nevedrova NN, Zol'nikov ID, Rusanov GG, Ponomarev PV (2012) Geoelectrical studies of the Chuya basin sedimentary fill (Gorny Altai). Russ Geol Geophys (Geologiya i Geofizika) 53(1):92-107

Deshpande SM, Aher KR (2012) Evaluation of groundwater quality and its suitability for drinking and agriculture use in parts of Vaijapur, District Aurangabad, MS, India. Res J Chem Sci 2(1):25-31

Durov SA (1948) Klassifikacija prirodnych vod i graficeskoje izobrazenie ich sostava. Doklady AK Nusk SSSR 59(1):87-90

Edet AE, Okereke CS (2001) A regional study of saltwater intrusion in southeastern Nigeria based on the analysis of geoelectrical and hydrochemical data. Environ Geol 40:1278-1289

El-Haddad AE, El-Akraby AM, Ismail IS, Abdel Gowad AM (2014) Investigation of groundwater potentiality in the eastern part of Qena, central Eastern Desert, Egypt, using 2-D homogeneous function method. Arab J Geosci 7(8):3011-3021

Griffiths DH, Barker RD (1993) Two-dimensional resistivity imaging and modeling in areas of complex geology. J Appl Geophys 29:211-226 
Khalil MH (2009) Hydrogeophysical assessment of wadi el-sheikh aquifer, saint katherine, south Sinai, Egypt. J Environ Eng Geophys 14(2):77-86

Mall R, Gupta A, Singh R, Singh RS, Rathore LS (2006) Water resources and climate change: an Indian perspective. Curr Sci 90(12): 25

Mondal NC, Das SN (2012) Evaluation and augmentation of safe drinking water supply schemes in Salur Mandal, Vizainagaram district, Andhra Pradesh. India. J Geol Soc India 80(1):57-64

Mondal NC, Singh VP (2012) Chloride migration in groundwater for a tannery belt in Southern India. Environ Monit Assess 184(5):2857-2879

Mondal NC, Das SN, Singh VS (2008a) Integrated approach for identification of groundwater potential zones in Seethanagaram Mandal of Vizianagaram District, Andhra Pradesh, India. J Earth Syst Sci 117(2):133-144

Mondal NC, Rao VA, Singh VS, Sarwade DV (2008b) Delineation of concealed lineaments using electrical resistivity imaging in granitic terrain. Curr Sci 94(8):1023-1030

Mondal NC, Singh VS, Rangarajan R (2009) Aquifer characteristics and its modeling around an industrial complex, Tuticorin, Tamil Nadu, India: a case study. J Earth Syst Sci 188(3):231-244

Mondal NC, Singh VP, Singh VS, Saxena VK (2010) Determining the interaction between groundwater and saline water through groundwater major ions chemistry. J Hydrol 388(1-2):100-111

Mondal NC, Singh VP, Ahmed S (2013) Delineating shallow saline groundwater zones from Southern India using geophysical indicators. Environ Monit Assess 185(6):4869-4886

Offiong OE, Edet AE (1998) Water quality assessment in Akpabuyo, cross River basin, South-estern Nigeria. Environ Geol 34:167-174

Petrović G (1980) Physico-chemical aspects of alkaline ponds in Yugoslavia. In: Dokuli M, Metz H, Jewson D (eds) Shallow lakes contributions to their limnology. Developments in hydrobiology, vol 3. Springer, Netherlands, pp 89-95

Prasad RK, Mondal NC, Singh VS (2008) Evaluation of groundwater resource potential using GIS in Kurmapalli watershed of Andhra Pradesh. J Geol Soc India 71(5):661-669

Ramesh R, Shivkumar K, Eswaramoorthy S, Purvaja GR (1995) Migration and contamination of major and trace elements in groundwater of Madras city, India. Environ Geol 25:126-136

Sankaran S, Sonkamble S, Krishnakumar K, Mondal NC (2012) Integrated approach for demarcating subsurface pollution and saline water intrusion zones in SIPCOT area: a case study from Cuddalore in Southern India. Environ Monit Assess 184(8):5121-5138

Sarwade DV, Singh VS, Puranik SC, Mondal NC (2007) Comparative study of analytical and numerical methods for estimation of aquifer parameters: a case study in basaltic terrain. J Geol Soc India 70:1039-1046
Saxena VK, Singh VS, Mondal NC, Jain SC (2003) Use of hydrochemical parameters for the identification of fresh groundwater resources, Potharlanka Island, India. Environ Geol 44(5):516-521

Scanlon BR, Jolly I, Sophocleous M, Zhang L (2007) Global impacts of conversions from natural to agricultural ecosystems on water resources: quantity versus quality. Water Resour Res 43:W03437. doi:10.1029/2006WR005486

Selvam S, Manimaran G, Sivasubramanian P, Balasubramanian N, Seshunarayana T (2014) GIS-based evaluation of water quality index of groundwater resources around Tuticorin coastal city, South India. Environ Earth Sci 71:2847-2867

Senosy AM, Dahab KA (1997) Geo-electrical and hydrogeochemical studies for delineating ground-water contamination due to saltwater intrusion in the northern part of the Nile Delta, Egypt. Ground Water 35:216-222

Siebert S, Burke J, Faures JM, Frenken K, Hoogeveen J, D̈oll P, Portmann FT (2010) Groundwater use for irrigation-a global inventory. Hydrol Earth Syst Sci 14:1863-1880

Sonkamble S, Sahya A, Mondal NC, Harikumar P (2012) Appraisal and evolution of hydrochemical processes from proximity basalt and granite areas of Deccan Volcanic Province (DVP) in India. J Hydrol 438-439:181-193

Sreedevi PD (2004) Groundwater quality of Pageru River basin, Cuddapah district, Andhra Pradesh. J Geol Soc India 64:619-636

Stallard RF, Edmond JM (1983) The influence of geology and weathering environment on the dissolved load. J Geophy Res 88:9671-9688

Subramanian S (1994) Hydrogeological studies of the coastal aquifers of Tiruchendur, Tamil Nadu. Ph.D. Thesis, Manonmaniam Sundaranar University, Thirunelveli

Sudo H, Tanaka T, Kobayashi T, Kondo T, Takahashi T, Miyamoto M, Amagai M (2004) Permeability imaging in granitic rocks based on surface resistivity and profiling. Expl Geophys 35:56-61

Theis CV (1935) The relationship between the lowering of the piezometric surface and the rate and duration of discharge of a well using ground-water storage. Am Geophys Union Trans $16: 519-524$

Thomas A (2008) Agricultural irrigation demand under present and future climate scenarios in China. Glob Planet Change 60:306-326

Todd DK (1980) Groundwater hydrology. Wiley, New York

Wilcox LV (1955) Classification and use of irrigation waters. US Dept Agric Circular 969, DC, p 19

World Health Organization (1984) Guideline of drinking quality (pp 333-335) Washington. World Health Organization, DC 